\title{
REDEPOSITED CONGLOMERATES IN A MIOCENE FLYSCH SEQUENCE AT BLACKMOUNT, WESTERN SOUTHLAND, NEW ZEALAND
}

\author{
ROBERT M. CARTER and RICHARD J, NORRIS \\ Department of Geology, Otago University, Dunedin (New Zealand)
}

(Received October 20,1975; revised and accepted June 28, 1976)

\begin{abstract}
Carter, R.M. and Norris, R.J., 1977. Redeposited conglomerates in a Miocene flysch sequence at Blackmount, western Southland, New Zealand, Sediment. Geol., 18: 289319.

The Middle Miocene Monowai Formation represents a gravel delta that prograded south into a flysch basin complex developed along the Moonlight Tectonic Zone, southern New Zealand. The delta-slope environment was characterized by a conglomeratic sequence up to $500 \mathrm{~m}$ thick. Most of the gravel was moved downslope by mass-transport processes. A complete spectrum exists from synsedimentary slide sheets (up to $10 \mathrm{~m}$ thick and $100 \mathrm{~m}$ long) that retain pre-sliding sedimentary structures, to more mature mass-transported sediment types in which all original structures have been destroyed. The most distal deposits include ungraded homogeneous pebble conglomerates up to $3 \mathrm{~m}$ thick. Some of the more mature redeposited conglomerate-sand-mud units $(X-Y-Z$ sequences) are between 2 and $10 \mathrm{~m}$ thick; they comprise a basal $X$-division of bouldery conglomerate, a middle $Y$-division of pebbly mudstone or pebbly sandstone, and an upper $Z$-division of hydroplastically folded mudstone. Though $X-Y-Z$ sequences may have been deposited from very proximal turbidity or fluxoturbidity currents, inertia-flow emplacement seems more likely. An inertia-flow mode of emplacement also seems most probable for the other redeposited sediment types described from the Monowai Formation.
\end{abstract}

\section{INTRODUCTION}

A number of recent papers have described redeposited conglomerates that occur in typical flysch sequences (Scott, 1966; Fisher and Mattison, 1968; Aalto and Dott, 1970; Hubert et al., 1970; Aalto, 1972; Hendry, 1973; Davies and Walker, 1974; Rocheleau and Lajoie, 1974). The problems of inferring the transport mechanisms of such coarse-grained sediments are considered by most of these authors, who discuss emplacement by various types of laminar, pseudolaminar or turbulent mass flow. Following the conventional interpretation of turbidity currents as the most mature of a range of subaqueous mass-transport processes (cf. Dott, 1963; Morgenstern, 1967), 
conglomerates such as those that Davies and Walker (1974) interpret as the deposits of powerful turbidity currents should grade laterally into sediment types that represent more proximal or immature types of redeposition. Few modern authors have yet described redeposited conglomerates of this most

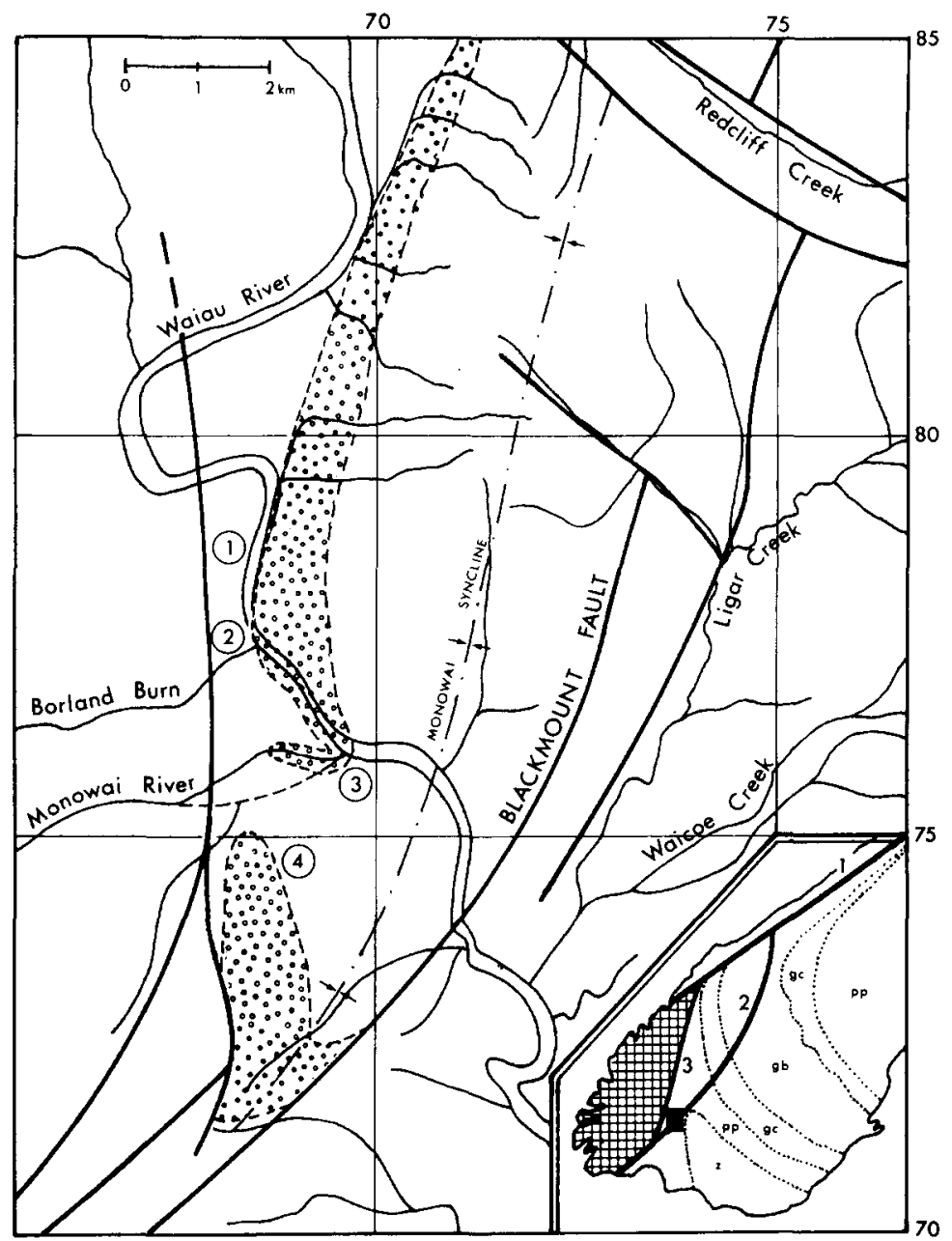

Fig. 1. Locality map of the Blackmount area showing the distribution of the Monowai conglomerate (open circles). Numbered localities show the position of major sections through the conglomerate: 1 = Blackmount West; 2 = Borland Burn-Waiau River junction (cf. Fig. 5); 3 = Monowai River (cf. Fig. 3); 4 = Conglomerate Ridge (cf. Fig. 6). Inset map of southern part of South Island showing $1=$ Alpine, $2=$ Moonlight, and $3=$ Eglinton-Hollyford fault systems, rocks of the Tuhua Orogen (cross-hachured), and the distribution of metamorphic zones within the Rangitata Orogen $(z=$ zeolite facies; $p p=$ prehnite-pumpellyite facies; $g c=$ greenschist (chlorite) facies; $g b=$ greenschist (biotite) facies). Position of Blackmount area indicated by black rectangle. Extension of the Moonlight fault system north to the Alpine Fault, beyond the chlorite schist belt, is hypothetical. 
proximal type (i.e. sequences that include slide sheets in varying stages of disruption and redeposition), though some earlier literature contains valuable descriptions of such sediments (Becker, 1916; Jones, 1939; Beets, 1946). This paper therefore presents a preliminary description of a well-exposed sequence of proximal redeposited conglomerates associated with a Cainozoic flysch basin in southern New Zealand.

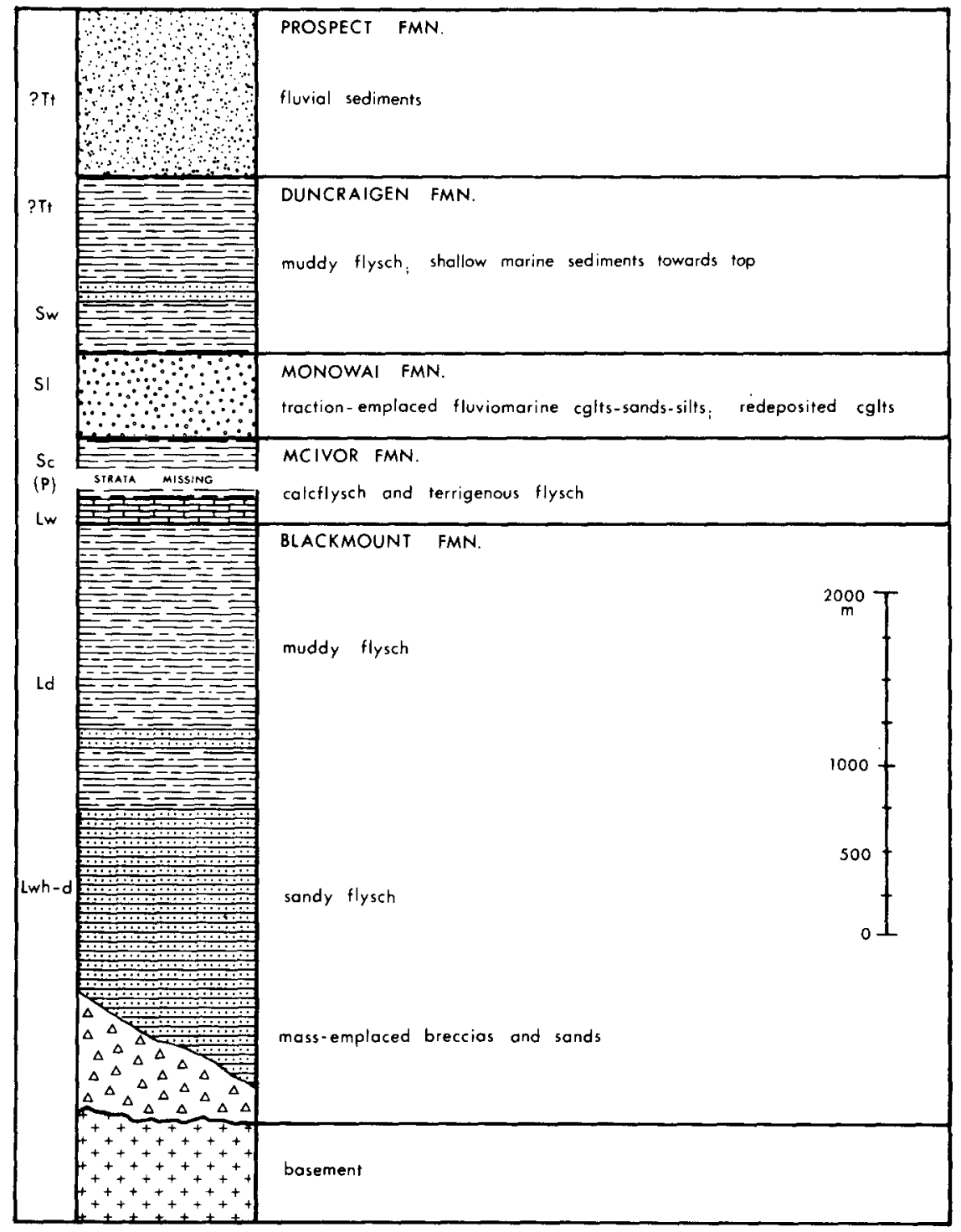

Fig. 2. Summary stratigraphic column of the Blackmount area. Abbreviations in left-hand column refer to local New Zealand biostratigraphic zonation. 


\section{REGIONAL SETTING}

The Monowai conglomerates occur within a thick Cainozoic flysch sequence that was deposited along the Moonlight fault system, southwestern New Zealand (Fig. 1). This system marks a fault-controlled graben complex which extends north from the southwestern margin of the New Zealand conti. nental plateau, and which originated as a result of Late Eocene-Oligocene plate boundary rearrangements in this part of the southwest Pacific (cf. Carter and Norris, 1976; Norris et al., in prep.). Oligocene to Pliocene flysch basins, controlled by faults of the Moonlight and Holly ford systems, developed along and adjacent to the active Moonlight Tectonic Zone, and suggest the zone may have been an aulacogen (Norris et al., in prep.; cf. Hoffman, 1973). Further changes in plate movements during the Late Miocene gave rise to reversal of movement on many of the faults with accompanying folding and uplift of the sediments. The sedimentary sequence exposed at Blackmount is typical of the fill of basins along the fault system. At Blackmount, between 5 and $10 \mathrm{~km}$ of post-Eocene sedimentary rocks can be grouped into five formations representing five regional tectono-sedimentary phases (Fig. 2).

Conglomerates of the Monowai Formation (Carter and Norris, in prep.) lie approximately in the middle of this thick redeposited sequence. They outcrop in a major north-plunging syncline to the west of the Blackmount Fault (Fig. 1), itself part of the Moonlight Tectonic Zone. The conglomerates show all gradations between rocks interpreted as synsedimentary slide sheets and rocks interpreted as internally mixed inertia-flow deposits.

More detailed information regarding access and the geologic and stratigraphic setting of the Monowai Formation may be found in Carter and Norris (in prep.). Stratigraphic terminology throughout follows Carter et al. (1974), whilst the sedimentologic terminology is after Sanders (1965) and Carter (1975).

\section{GENERAL DESCRIPTION OF THE MONOWAI FORMATION}

\section{Rock types}

The characteristic lithology is a rusty-brown weathering roundstone conglomerate with pebbles of metagreywacke and semischist set in a matrix of medium to granular sand. Conglomerate beds are up to $5 \mathrm{~m}$ thick and only rarely show sedimentary traction structures. Many beds are massive and lack primary bedding features, but some exhibit internal structures such as nor$\mathrm{mal}$ and reverse grading and thin mudstone partings. The conglomerates occur interbedded with sandstones and mudstones over a total thickness of at least $500 \mathrm{~m}$. Finer-grained lithologies between conglomerate bands outcrop poorly away from the river sections, resulting in the impression that the formation is conglomerate dominated; in fact, only $20-30 \%$ of the sequence is composed of homogeneous conglomerate (cf. Aalto and Dott, 1970). 


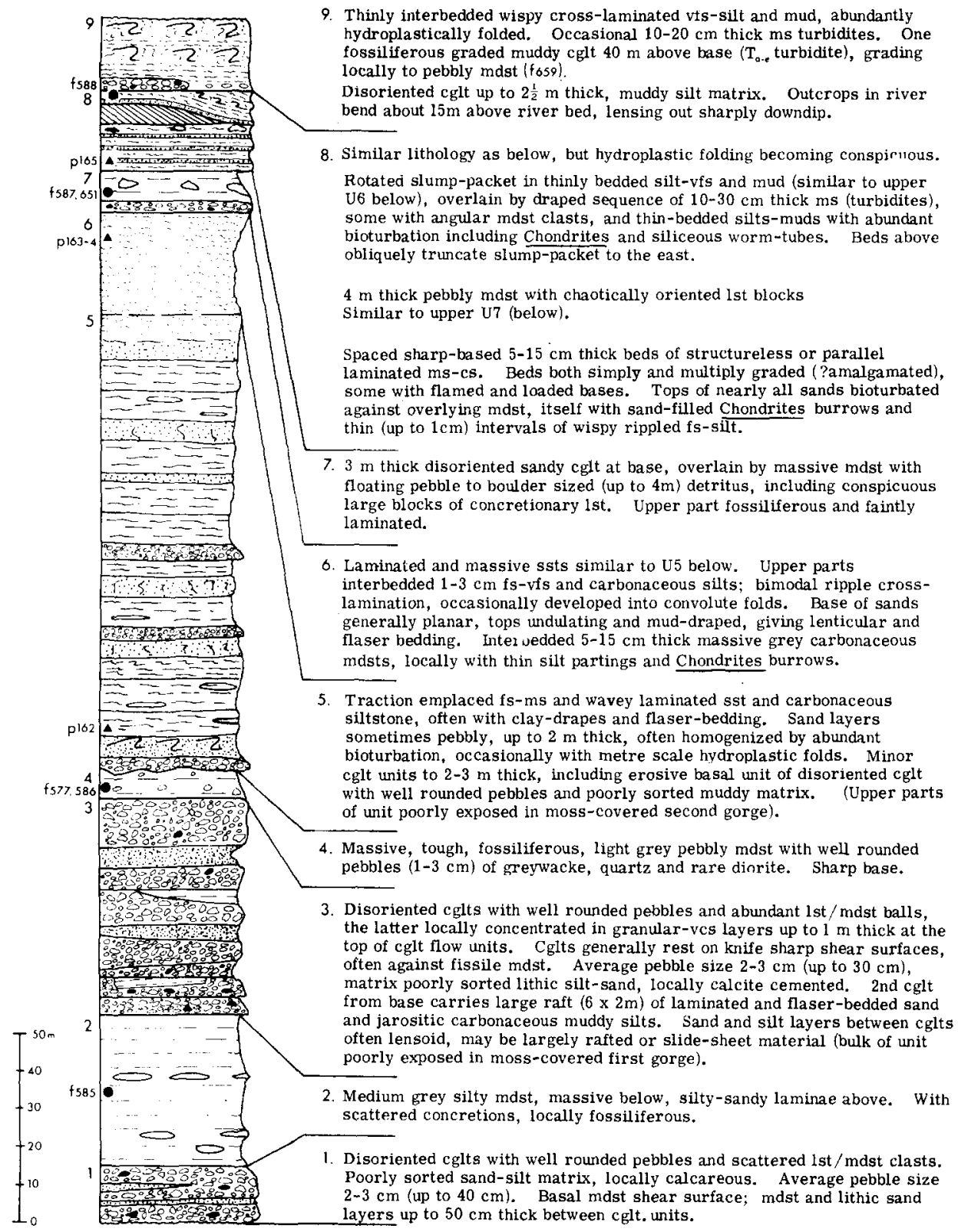

Fig. 3. Measured section through the middle to upper parts of the Monowai Formation (units 1-8) and the basal Duncraigen Formation (unit 9) in Monowai River. (Modified after an unpublished column by G. Morrison.)

In the well-exposed section in the Monowai River (Figs. 1,3), the middle parts of the formation (units 5-6 of Fig. 3) are dominantly fine grained and contain shallow-marine sedimentary structures, particularly bioturbated muddy sands and alternating flaser- or lenticular-bedded, ripple cross-lami- 
nated sands and muds. The muds are dark coloured and carbonaceous, and contrast markedly with the thick, massive, medium-grey, calcareous mudstones with marine fossils that occur between conglomerate bands towards the base of the formation (cf. unit 2 of Fig. 3.). Thus, for the Monowai River section at least, the lower to middle part of the Monowai Formation represents a regressive sequence, with successive units representing shoaler-water conditions successively nearer to the basin margin.

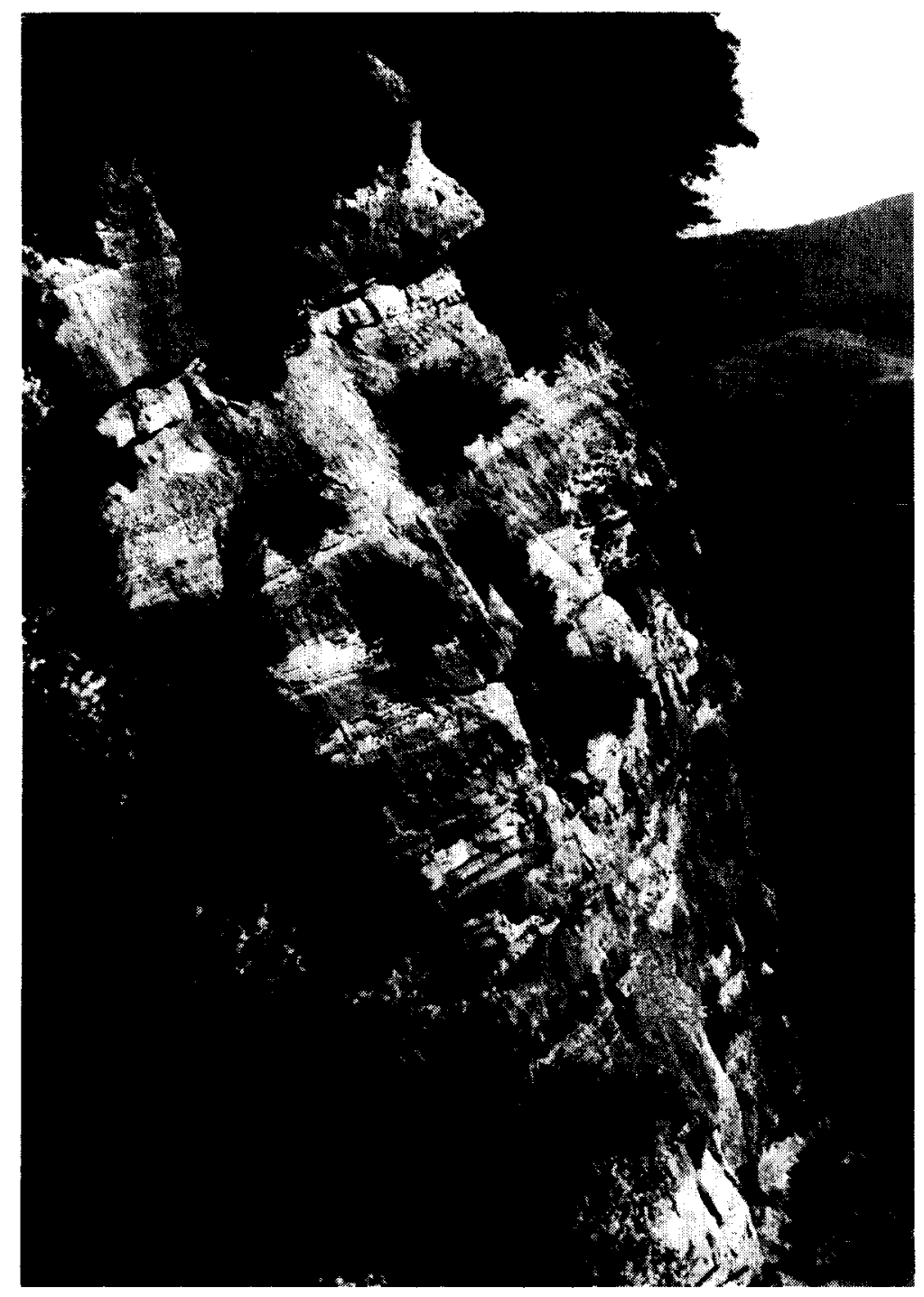

Fig. 4. Rhythmically bedded fining-upward conglomerate-sand-silt cycles of the Monowai Formation at Blackmount West. 
In the cliffs at Blackmount West (Fig. 1), the conglomerates contain sedimentary structures typical of traction currents, including channels, lowangle tabular cross-beds and imbricated clasts. Furthermore, conglomerates often grade into the overlying sand-silt lithologies, and form repetitive fining-upward cycles (Fig. 4). Such lithofacies suggest a shallow-fluviomarine environment, most probably the top of a gravel delta on which the con-
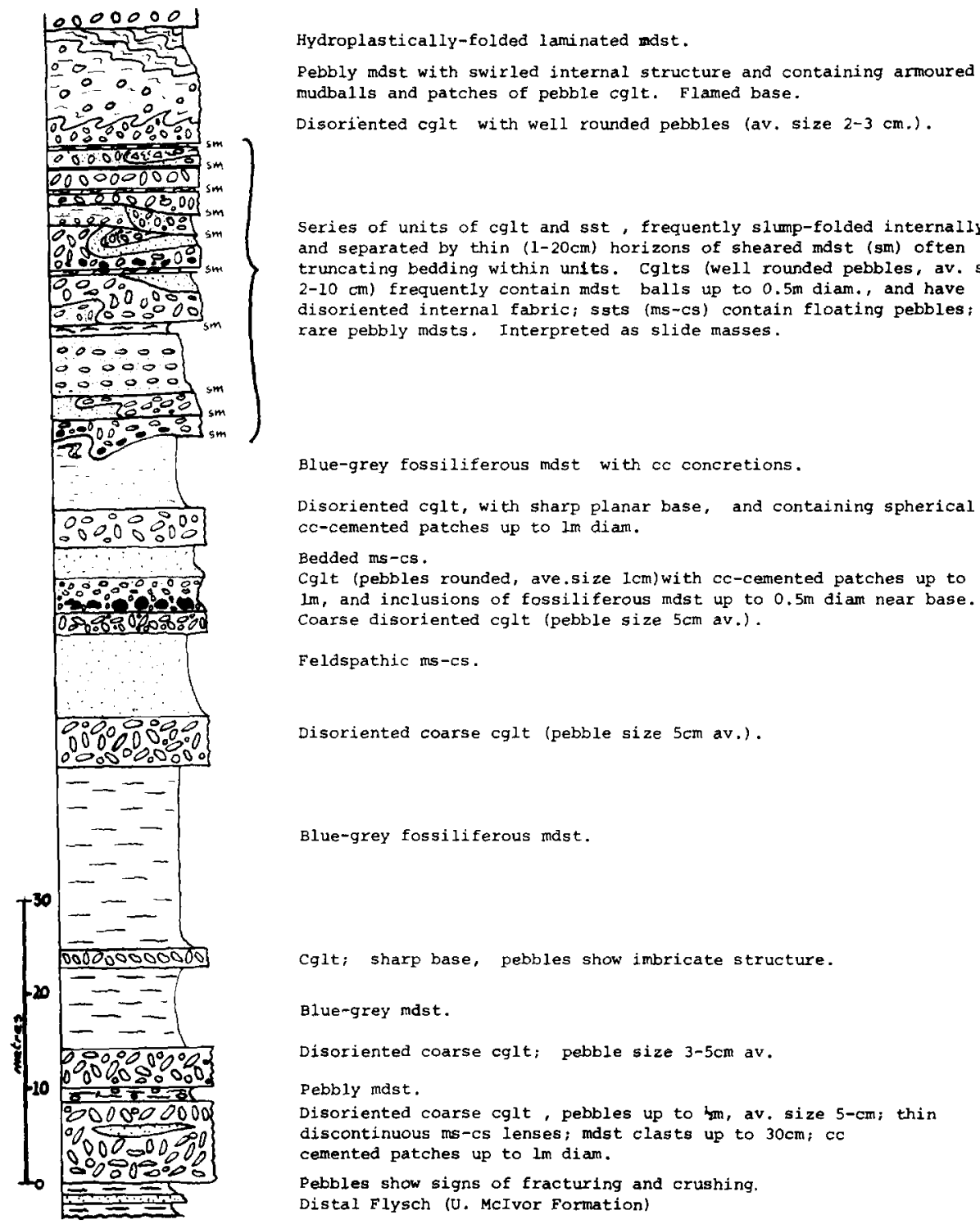

Fig. 5. Measured section through the basal Monowai Formation on the south bank of the Waiau River, east of the Borland Burn junction. 


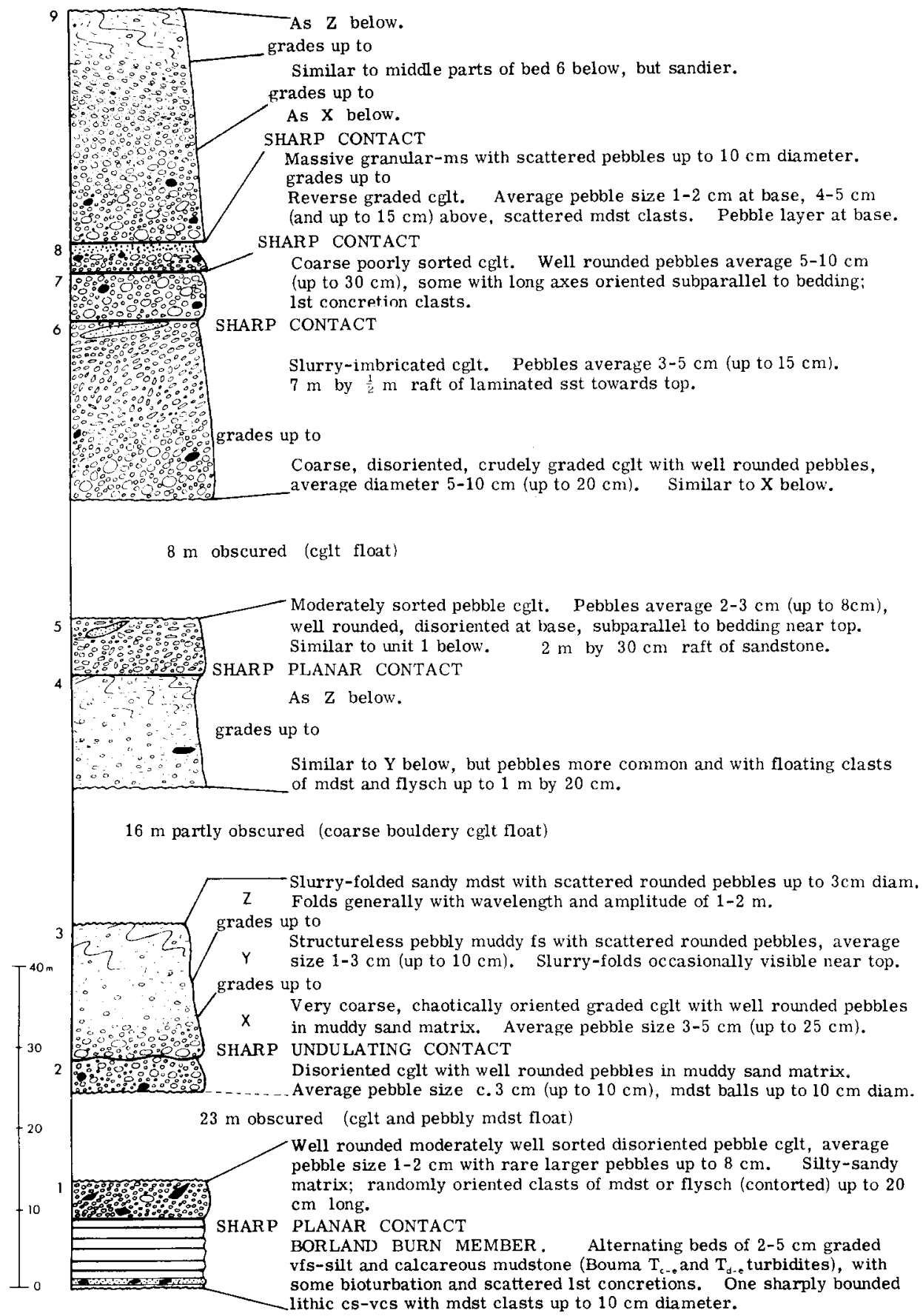

Fig. 6. Measured section through the basal Monowai Formation on farm track on the west side of Conglomerate Ridge. 
glomerates and sands represent channel fills, and silts and muds overbank deposition.

Structural complications (cf. Fig. 1) make it difficult to be sure of the precise equivalents of the deltaic facies further to the south, but the most likely interpretation is that the deltaic sediments of Blackmount West grade laterally into the shallow-marine (?delta front) sediments represented by units 5-6 of the Monowai River sequence (Fig. 3). Hence (1) a broadly regressive, or distal-proximal upwards, sedimentary pattern probably characterises the Blackmount West section, similar to that inferred for the Monowai River section; and (2) a proximal (in the north) to distal (in the south) lateral trend is also indicated, at least for the middle parts of the formation.

\section{Contacts}

The basal contact of the Monowai Formation is well exposed at three localities (cf. Figs. 5, 6). In all cases the contact is a knife-sharp sedimentary shear plane, with redeposited conglomerate resting on typical terrigenous flysch of the Borland Burn Member of the McIvor Formation (Fig. 7). Bedding above and below the contact is strictly parallel. Thus the arrival of the

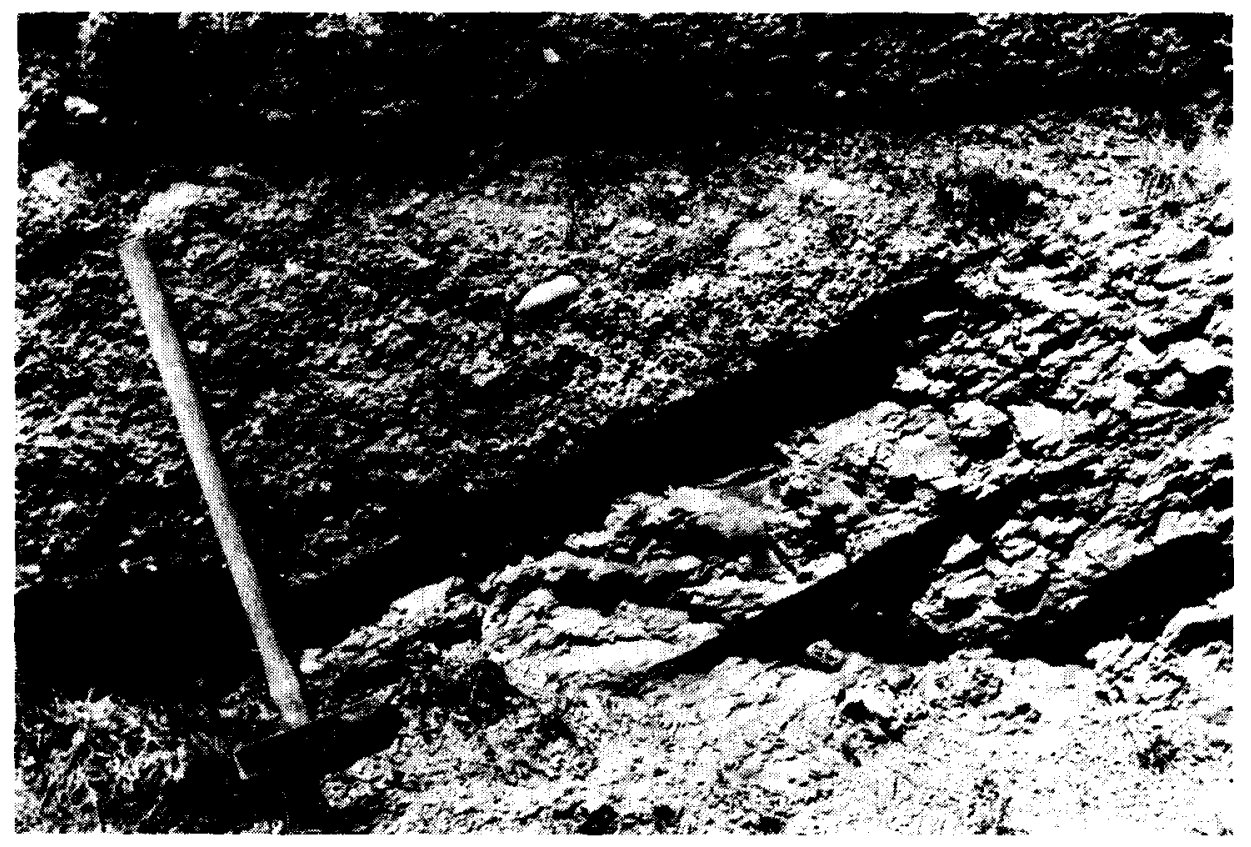

Fig. 7. Basal unit of the Monowai Formation, west side of Conglomerate Ridge (unit 1 of Fig. 6). Sharp contact against muddy flysch of the Borland Burn Member of McIvor Formation. Hammer $=80 \mathrm{~cm}$. 
first redeposited conglomerate of the Monoway Formation marked a sudden change in the regional sedimentary regime.

In contrast, the upper parts of the Monowai Formation pass gradually up into terrigenous flysch of the overlying Duncraigen Formation (cf. Fig. 3). The upper parts of the Monowai River (units 7-8) and Blackmount West sections show the reappearance of redeposited conglomerates above the in situ traction-emplaced deltaic facies, and above these conglomerates the section rapidly passes into thick terrigenous flysch.

Fossils

The flysch that underlies (McIvor Formation) and overlies (Duncraigen Formation) the Monowai conglomerates contains diverse foraminiferal assemblages and deep-water benthic invertebrate assemblages. Turrid gastropods comprise a conspicuous and dominant part of the benthic fauna. The mudstones interbedded low in the Monowai Formation yield a somewhat poorer microfauna, while fossils are generally lacking in the middle and upper parts of the formation. The combined faunal evidence suggests a Middle Miocene (Clifden-Lillburn Oppelzone) age .

The richest macrofauna within the Monowai Formation occurs in a pebbly mudstone (unit 4) in the Monowai River section. Thick-shelled shallow-water molluscs predominate, including Glycymeris and Tropicolpus. The shells are somewhat worn and battered, bivalves are present as single valves, and the fauna has clearly been transported from its original habitat. A similar fauna, but including Struthiolaria, occurs rarely in penecontemporaneous mudstone or limestone clasts within thick conglomerate beds. Otherwise, the sole fauna seen in the conglomerate beds themselves is a single valve of the large ostreid Pycnodonte (middle parts of the formation at the south end of Conglomerate Ridge), and two probable Ophiomorpha burrows (amongst the slide-sheet complexes of the middle part of the formation on Conglomerate Ridge; see page 313 ).

Thus the faunal evidence is consistent with the Monowai Formation representing shallow-water sediments that were prograding out into basinal, openmarine environments. The paucity but not absence of macrofauna, in particular, is good supporting evidence for the fluviomarine environments of deposition already inferred on sedimentological grounds.

\section{Environment of deposition}

The faunal and sedimentary evidence described above is perhaps open to two alternative interpretations; either the Monowai Formation accumulated as a deep-marine fan, or on a shallow-marine delta and delta slope. Submarine fan-type sedimentation is well developed in the formations above and below the Monowai conglomerates, particularly in the Blackmount Formation (cf. Fig. 2; also Carter and Norris, in prep.). We wish to emphasise, 
therefore, that the Monowai conglomerates are unlike typical fan sediments in several important ways, notably (1) comprising much thicker sequences of conglomerate than is typical of fan-channel situations; (2) containing appreciable amounts of traction-emplaced sediment, some of which contains structures such as flaser bedding, typically of shallow-water origin; and (3) containing appreciable numbers of large shallow-marine benthonic organisms, coupled with an absence of the deep-water faunas that characterise the formations above and below.

With this evidence in mind, we prefer an interpretation of the Monowai Formation as a delta and delta slope deposit.

\section{Provenance}

The clast assemblage of the Monowai Formation (Fig. 8A) is dominated by fine to medium grained volcanogenic metagreywackes and microbreccias ("chipwackes") with appreciable but lesser amounts of slightly higher grade subschistose metasediment. Associated minor rock types include black or maroon argillites and vein quartz. Many metasedimentary pebbles have veins, usually combinations of quartz, epidote and pumpellyite. Porphyritic basic volcanics are absent and though some leucogranite/leucogneiss clasts occur they are extremely rare (one clast only occurring in quadrat pebble counts that totalled 500 pebbles). All clasts are fresh and of flinty hardness (subschistose pebbles are somewhat crumbly but this probably reflects recent weathering in the outcrop), and rounding is generally well advanced. Clast sizes in excess of $15 \mathrm{~cm}$ are rare and the average pebble size lies in the $2-10$

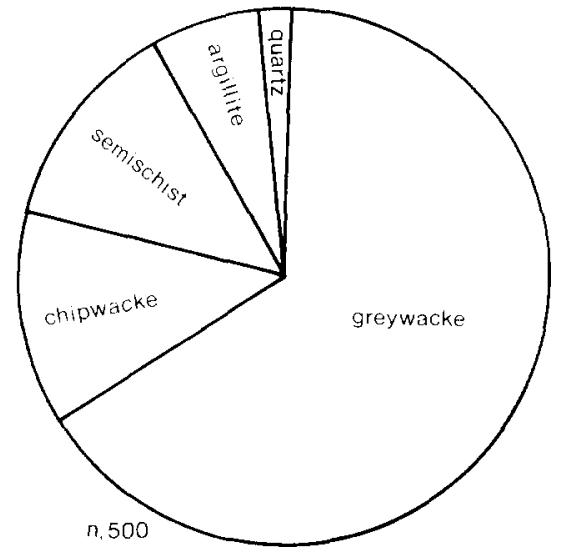

(A)

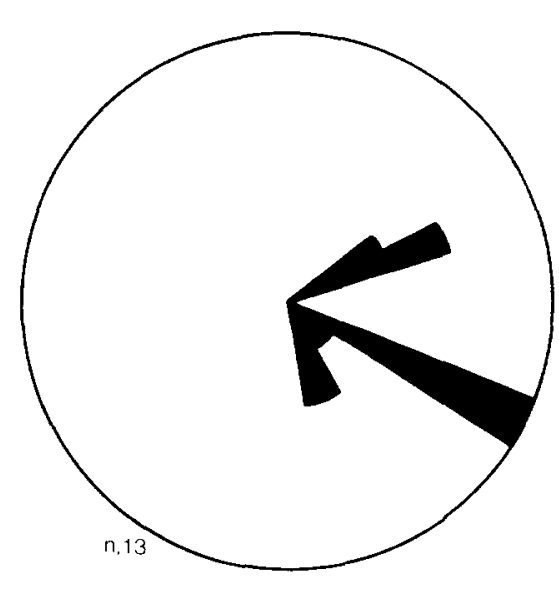

(B)

Fig. 8. A. Pebble-count data from the Monowai Formation. B. Directional slope indicators (hydroplastic folds, flames) from the Monowai Formation. 
$\mathrm{cm}$ range. These textural criteria combine with the petrographic to indicate a relatively distant source area for the Monowai Conglomerates. Directional data (Fig. 6b) are not abundant but imply a northwest to southeast palaeoslope (flame structures and hydroplastic folds).

The clast assemblage of the Monowai Formation is representative neither of the high-grade plutonic/metamorphic terrain of Fiordland to the west, nor of the intermediate volcanic terrain of the Takitimu Mountains to the east, but matches in almost every detail lithologies in the low-grade metagreywacke belt that flanks the south of the main schist belt of the Rangitata Orogen to the north (Fig. 1). We conclude, therefore, that the dominant provenance area for the Monowai conglomerates was the South Otago-Nelson Metagreywacke Zone (Carter et al., 1974; Caples "Group" of many earlier writers), a source area at closest $50 \mathrm{~km}$ north and east of Blackmount. This inference is supported by the fact that the Monowai Formation is not known to occur south of Blackmount, but is present and has an identical clast assemblage at localities between Blackmount and the metagreywacke zone.

\section{Summary}

The Monowai Formation represents the deposits of a gravel delta system that prograded from the north into the Blackmount flysch basin. The deposits of this prograding wedge of "molasse" reached Blackmount in the Middle Miocene (Clifden Oppelzone), after which further basin depression took place and resulted in the replacement of shallow-fluviomarine sediments (parts of the Monowai Formation) by further flysch-basin deposits (Duncraigen Formation). For a brief period in the Middle Miocene the deltafront slope in front of the prograding Monowai Formation was located at Blackmount, and the Monowai Formation at Blackmount is therefore largely made up of proximal redeposited conglomerates. These redeposited conglomerates are described in more detail below.

\section{THE REDEPOSITED CONGLOMERATES OF THE MONOWAI FORMATION}

\section{Theoretical depositional models}

Proximal mass-transport mechanisms include a complex spectrum of laminar, pseudolaminar and perhaps turbulent suspension processes, (cf. Dott, 1963; Johnson, 1970; Carter, 1975), and they will therefore require a variety of depositional models for their characterisation. Yet one of the major problems in the description of coarse-grained redeposited sediments is the lack of widely applicable descriptive-genetic models (cf. Davies and Walker, 1974). The problem is highlighted by the appearance of three recent papers (Aalto and Dott, 1970; Rocheleau and Lajoie, 1974; Davies and Walker, 1974) which describe characteristic sequences of internal bedforms in redeposited 
conglomerates, yet these bedform sequences differ widely from one suite of conglomerates to another. It is therefore clear that there is no single, simple, universally applicable Bouma sequence analogue that can be applied to coarse-grained redeposited sediments. Since our field data generally do not easily fit previously described depositional models, and since some beds within the Monowai conglomerates apparently contain their own characteristic sequences of internal bedforms, we distinguish below three major types of conglomerate or conglomerate-sand-mud facies, describing them in inferred depositional order from most distal (first) to most proximal (last).

\section{Ungraded homogeneous pebble conglomerates}

These beds are generally well sorted and comprise chiefly $1-3 \mathrm{~cm}$ diameter well-rounded pebbles. (Fig. 7). Scattered larger clasts up to $8 \mathrm{~cm}$ long generally have their long axes parallel with the bedding; penecontemporaneously derived chunks of mudstone and flysch $5-20 \mathrm{~cm}$ long and often hydroplastically contorted also occur, together with rare larger rafts of sandstone or flysch up to $2 \mathrm{~m}$ long. The constituent pebbles are set in a matrix of muddy sand, and often show a marked parallelism between clast long-axes and bedding. Beds of this facies rarely exceed $3 \mathrm{~m}$ in thickness, and may have knife-sharp bases (Fig. 7).

Extremely similar, if not identical, redeposited conglomerates have been described by Aalto and Dott (1970) under the heading Ungraded Pebble Deposits. At Blackmount they occur mainly in the lower parts of the Conglomerate Ridge sequence (units 1 and 5 of Fig. 6).

Interpretation. The ungraded nature of the homogeneous pebble conglomerates renders it unlikely that they were transported in fully turbulent suspension. The textural criteria, particularly the parallelism of clasts and bedding, indicate a laminar shearing mode of deposition, and we thus infer that these beds were emplaced by inertia flow. Mixing during transport was clearly sufficient to destroy any sedimentary structures on grain-size differentiation produced during the original (shallow-water) deposition of the bed. The presence of mudstone clasts indicates erosion of the seafloor over which the inertia flow was travelling, and the generally knife-sharp basal contacts suggest that en-bloc sliding accompanied the final stage of bed emplacement.

\section{Graded conglomerates - sands - muds $(X-Y-Z$ sequences $)$}

The conglomerate-sand-mud beds are generally normally graded and contain a characteristic sequence of internal structures associated with the gradually declining grain size upwards through the bed. This sequence of internal structures, here formalised as an $X-Y-Z$ sequence, is broadly analogous to the Bouma sequence as seen in typical turbidites.

$X-Y-Z$ sequences are between 5 and $10 \mathrm{~m}$ thick and comprise three main 

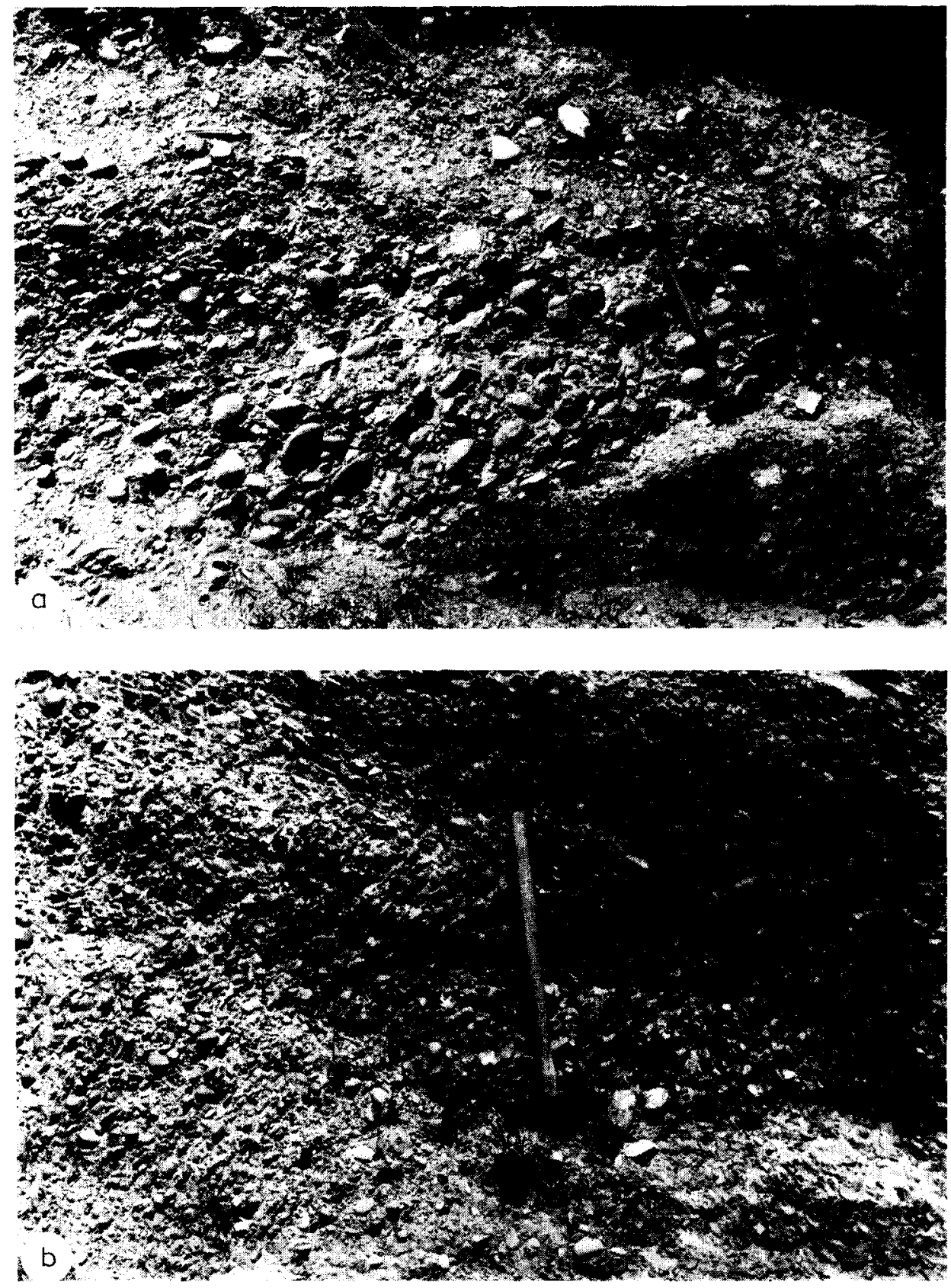

Fig. 9. Photographs of a typical $X-Y-Z$ conglomerate-sand-mud cycle (hammer in all cases $80 \mathrm{~cm}$ long; beds dip to left at ca $30^{\circ}$ ).

a. Bouldery conglomerate of $X$-division rests sharply upon underlying conglomerate, hammer head on contact (unit 2-3 contact of Fig. 6).

b. Slurry-imbricated conglomerate as seen in the upper part of some $X$-divisions (middle part of unit 6 of Fig. 6 ). 

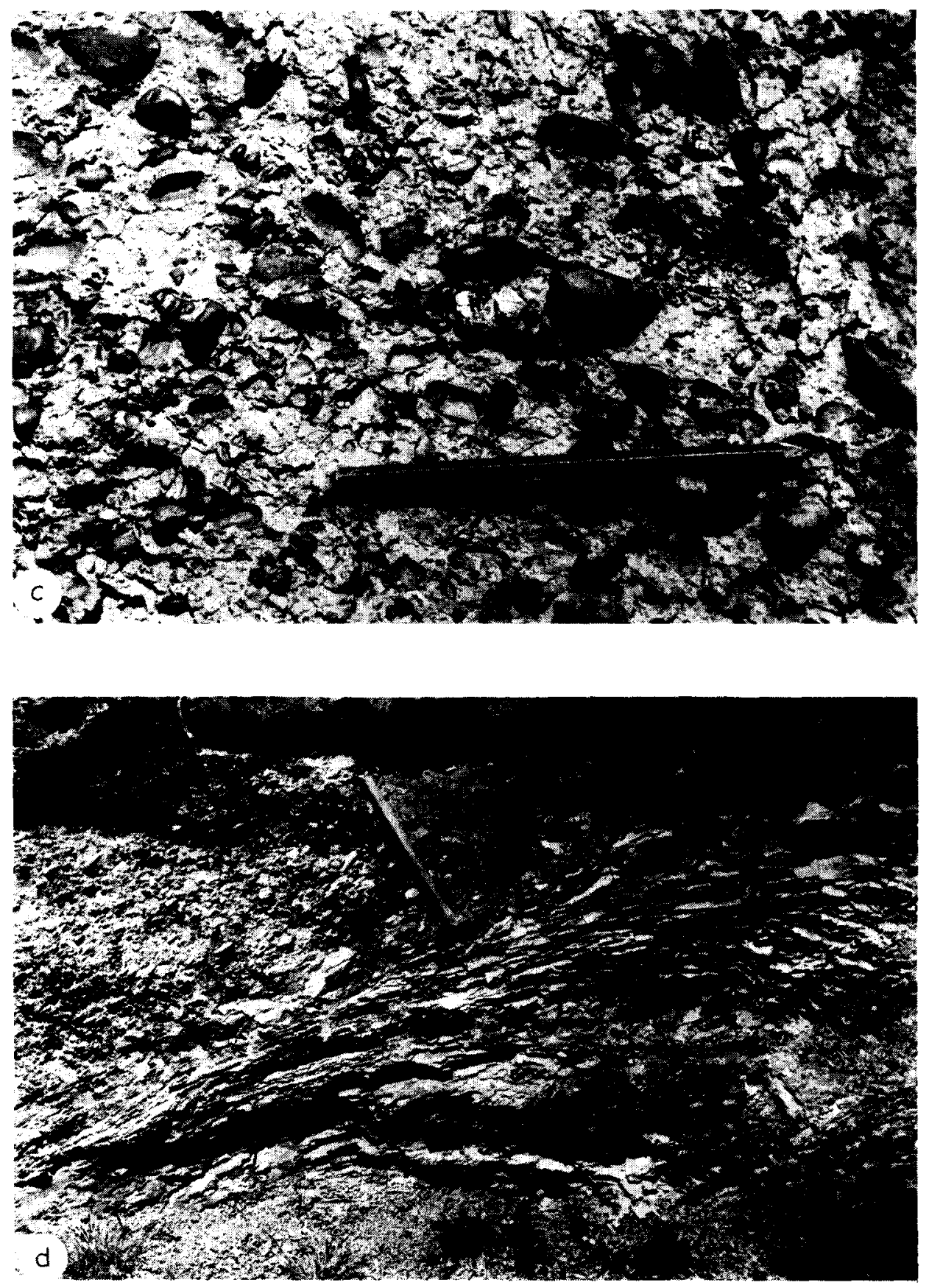

c. Pebbly mudstone of $Y$-division (unit 3 of Fig. 6).

d. Slurry-folded sandy mudstone of $Z$-division, sharply truncated by overlying conglomerate (unit 4-5 contact of Fig. 6). 
subdivisions, usually of roughly equal thickness (Fig. 6). The basal $X$-division consists of coarse, chaotically bedded, grain-supported, bouldery conglomerate (Fig. 9a). The pebbles are well to very well rounded and range from 3 to $10 \mathrm{~cm}$ in diameter; rare clasts may reach $30-40 \mathrm{~cm}$ in diameter, and the interclast matrix is a poorly sorted, muddy, lithic sand. The base of the $X$-division is invariably sharp, either planar or gently undulating on a wavelength of $20-50 \mathrm{~cm}$ and amplitude of $5-10 \mathrm{~cm}$ (Fig. 9a). The basal metre or so of the $X$-division generally contains a concentration of larger $10-20 \mathrm{~cm}$ diameter pebbles (i.e. the division itself is graded) which may show some tendency for long-axis alignment parallel to the bedding. The middle and upper parts of the $X$-division generally comprise somewhat better-sorted and finergrained conglomerates (average clast size $3-6 \mathrm{~cm}$ ), passing from chaotically oriented and unbedded conglomerates up into conglomerate in which the long axes of the clasts display "slurry imbrication", i.e. define swirly folds related to hydroplastic deformation at the moment of emplacement (Fig. $9 \mathrm{~b}$ ). Though penecontemporaneously derived clasts and rafts of soft sediment may occur at any level within the $X$-division, they are more common in the upper parts where rafts of sandstone may reach $7 \mathrm{~m}$ in length; most such clasts show soft-sediment (hydroplastic) deformation. The Y-division (Fig. $9 \mathrm{c}$ ), a classic pebbly mudstone or pebbly sandstone in the sense of Crowell (1957), gradationally overlies the $X$-division. Rounded $1-3 \mathrm{~cm}$ diameter pebbles (more rarely up to $10 \mathrm{~cm}$ ) float in structureless, homogeneous grey mudstone, sandy mudstone or (more rarely) sandstone. The passage to the $Z$-division is again gradual, being marked by a decline in the number of pebbles and the concomitant appearance of large hydroplastic folds of about 1-3 $\mathrm{m}$ wavelength and amplitude (Fig. 9d). These folds are usually particularly conspicuous at the top of the bed where they are sharply truncated by the overlying redeposited bed.

The intra-bed $X-Y-Z$ changes are gradational and, as in the case of the Bouma turbidite sequence, they represent a notional or ideal sequence. Though some beds show a full $X-Y-Z$ sequence, in others either the upper or lower parts are absent. For instance, some fairly thick (up to $3 \mathrm{~m}$ ) homogeneous conglomerate layers show a slurry imbrication towards their base that parallels large flame structures developed on top of the underlying finergrained sediments (Fig. 10); though possibly a discrete type of mass flow, these beds are provisionally interpreted as $Y-Z$ (i.e. base absent) sequences.

Fig. 10. Slurry-imbricated conglomerate unit at ridge crest at north end of Conglomerate Ridge. Hammer $=80 \mathrm{~cm}$ long.

a. Conglomerate is $4 \mathrm{~m}$ thick and has irregularly flamed base against the underlying sand unit; overlain at top right-hand side of outcrop by a small conglomerate slide packet. View northwest, palaeoslope component from left (north) to right.

b. Detail of large flame structure drawn out from the underlying sand at the base of the conglomerate unit of Fig. 10a. Note subparallelism of pebble long axes with the outlines of the flame. 

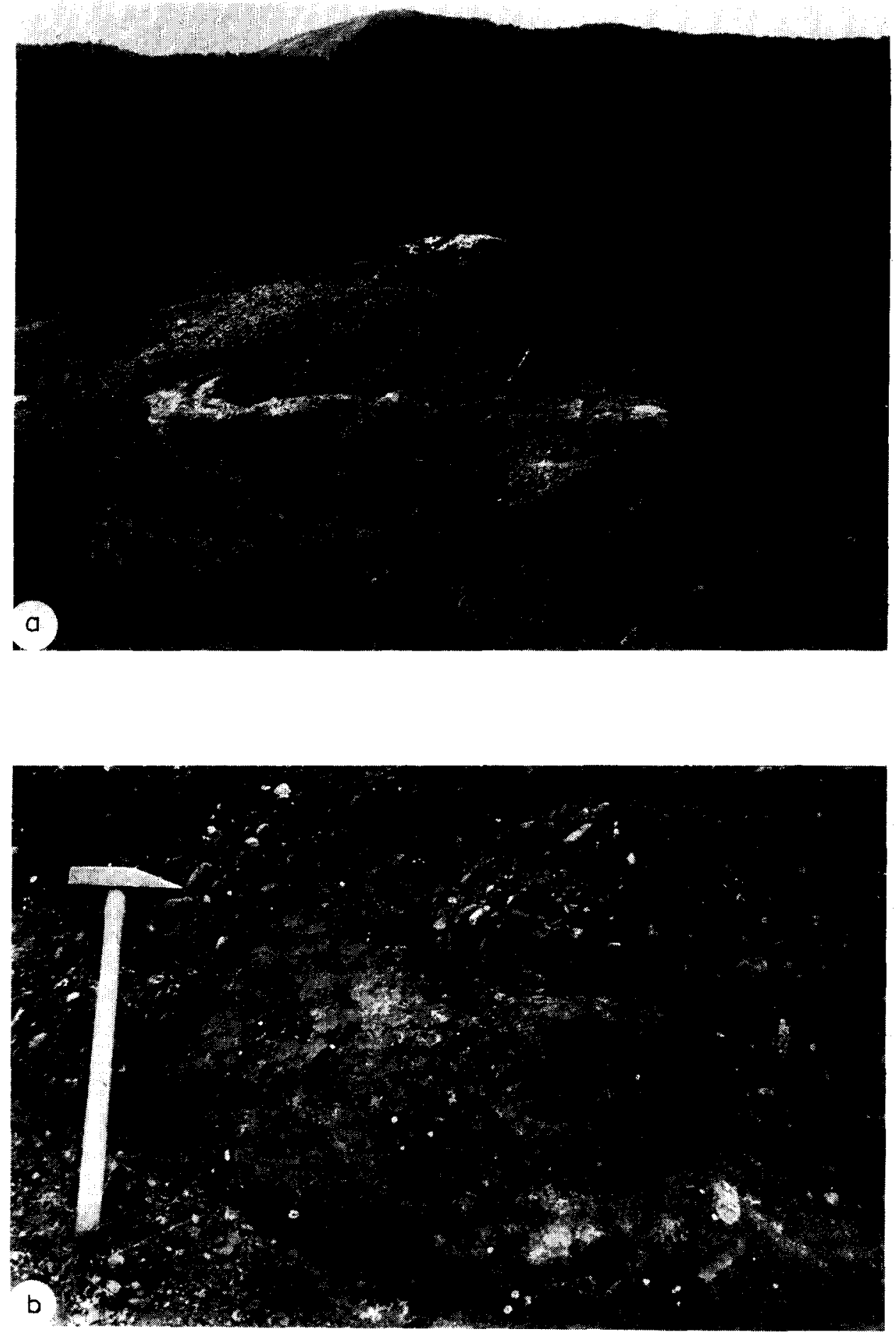
At least four superposed $X-Y-Z$ sequences occur along the western foot of Conglomerate Ridge (Fig. 6), and one such unit occurs at the top of the measured section along the Waiau River (Fig. 5). Similar conglomerate sequences have been recorded by Scott (1966; though not, of course, as $X-Y-Z$ sequences) from the Laga Sofia conglomerates in a Cretaceous flysch sequence in Chile. Scott's columns show that up to seven superimposed conglomerate-sand-mud sequences may occur, cumulatively totalling as much as $40 \mathrm{~m}$ in thickness; one individual $X-Y-Z$ sequence apparently attains a thickness of $30 \mathrm{~m}$ (Scott, 1966, fig. 28).

Interpretation. In spite of the very coarse grain sizes and the large bed thicknesses involved, the development of both distribution and coarsetail grading shows that the $X-Y-Z$ sequences were emplaced from relatively mature mass flows which had travelled far enough to allow considerable sorting and differentiation of grain sizes during transport. To many geologists, this strongly developed grading would represent prima-facie evidence for emplacement by turbidity currents. Whilst conceding this possibility, we agree with Scott (1966) that other possibilities should be considered.

The presence of hydroplastic folds in the $Y$ - and $Z$-divisions demonstrates that the final emplacement involved viscous or plastic sediment movement. The alignment of pebbles in the upper $X$ - and $Y$-divisions around the outlines of such hydroplastic folds indicates that the immediately preceding stage of transport was by some type of flow (?laminar or pseudolaminar) which was able to produce the orientation of pebbles parallel to flow streamlines. It could perhaps be argued that the broadly graded nature of the bed was produced during an earlier dominantly turbulent phase of transport (cf. Davies and Walker, 1974). However, the $Z$-layer at least is most unlikely to have ever been in turbulent suspension, since it could not have settled in time to allow its hydroplastic deformation with the $X-Y$ layers (unless this happened by post-depositional creep, for which we lack any other evidence). Together with the conspicuous lack of any traction fallout structures in the $X-Y$ layers, this argument persuades us that the $X-Y-Z$ sequences were most probably transported and emplaced by inertia flow.

The conclusion that $X-Y-Z$ sequences were deposited from inertia flows rather than turbidity flows implies that well-developed normal grading can originate during laminar or pseudolaminar mass transport. It is well established that differentiation of grain sizes may take place during laminar mass transport, for example the sorting of larger clasts to the top and front of a debris flow (cf. Johnson, 1970), but such processes have generally been inferred to result in inverse rather than normal grading (e.g. Fisher, 1971). However, both experimental and detailed field data are scanty, as witnessed by the numerous competing explanations for the production of dispersive pressure (and thus characteristic intra-bed textures) in a laminar mass flow (see summary in Carter, 1975). In the present state of knowledge, it remains possible that one or more intra-flow mechanisms may produce normal grading in an inertia flow. 
Though our field data suggest that some inertia flows produce well-developed normal grading, it is not clear by what precise means such grading is produced. Simple gravity settling of the largest boulders to the base of the flow may play a part, but the proper resolution of this problem must await more detailed field studies and experimental work.

A further interesting implication of the $X-Y-Z$ sequence is the demonstration that some pebbly mudstones comprise a repetitive division within an intrabed sequence characteristic of redeposited conglomerates. Crowell's (1957) hypothesis of slumping and mixing of gravel and mud, but without sufficient fluidity for the settling of the pebbles, remains broadly valid, but for those pebbly mudstones found within an $X-Y-Z$ sequence there has in fact been very considerable settling of the pebbles through to the basal $X$-division. Many pebbly mudstones that apparently occur "randomly" in coarse redeposited facies may therefore represent base and/or top absent $(X)-Y-$ $(Z)$ sequences (e.g. unit 4 of the Monowai River section, Fig. 3; many examples in Crowell, 1957, and Scott, 1966).

Excellent examples of base-truncated sequences (though not directly interpreted as such) have been presented by Scott $(1966$, p. 98): "lateral change from a unit consisting of graded conglomerate in the lower part and pebbly mudstone at the top to a bed consisting only of pebbly mudstone is common. If traced further, one pebbly mudstone may lose all clasts, becoming a structureless bed of mudstone or sandy mudstone containing contorted layers of sandstone"; and Scott's figured example (figs. 28-29) shows a 30 $\mathrm{m}$ thick $X-Y-Z$ conglomerate-mudstone sequence passing distally to a $6 \mathrm{~m}$ thick homogeneous pebbly mudstone over a distance of $6 \mathrm{~km}$. Scott's description and figures demonstrate that these lateral facies changes take place by the successive disappearance of the lower parts of the bed in a downtransport direction; there is thus a direct analogy to be drawn with the changes that take place in turbidites as one goes from proximal (Bouma a or $b$ based cycles) to distal (c or d based cycles).

\section{Slide-sheet conglomerates}

Towards the middle of the Monowai Formation, above the main development of full $X-Y-Z$ sequences, conglomerate beds begin to show thin intrabed synsedimentary shear zones, often demarcated by one to a few centimetres of lithified mudstone. These shear surfaces first appear in extremely poorly sorted, homogeneous, muddy or sandy conglomerates, the bases of which show large flame or drag-fold features against the underlying finergrained sediment (Fig. 11). Characteristically, beds with internal shear planes of this nature show a strong alignment of the long axes of constituent pebbles parallel to the shear partings, and are characterised by poor sorting (Fig. 12 ).

Still higher in the sequence the full development of slide sheets is seen. Individual sheets are generally $2-10 \mathrm{~m}$ thick and 20 to at least $100 \mathrm{~m}$ long. 


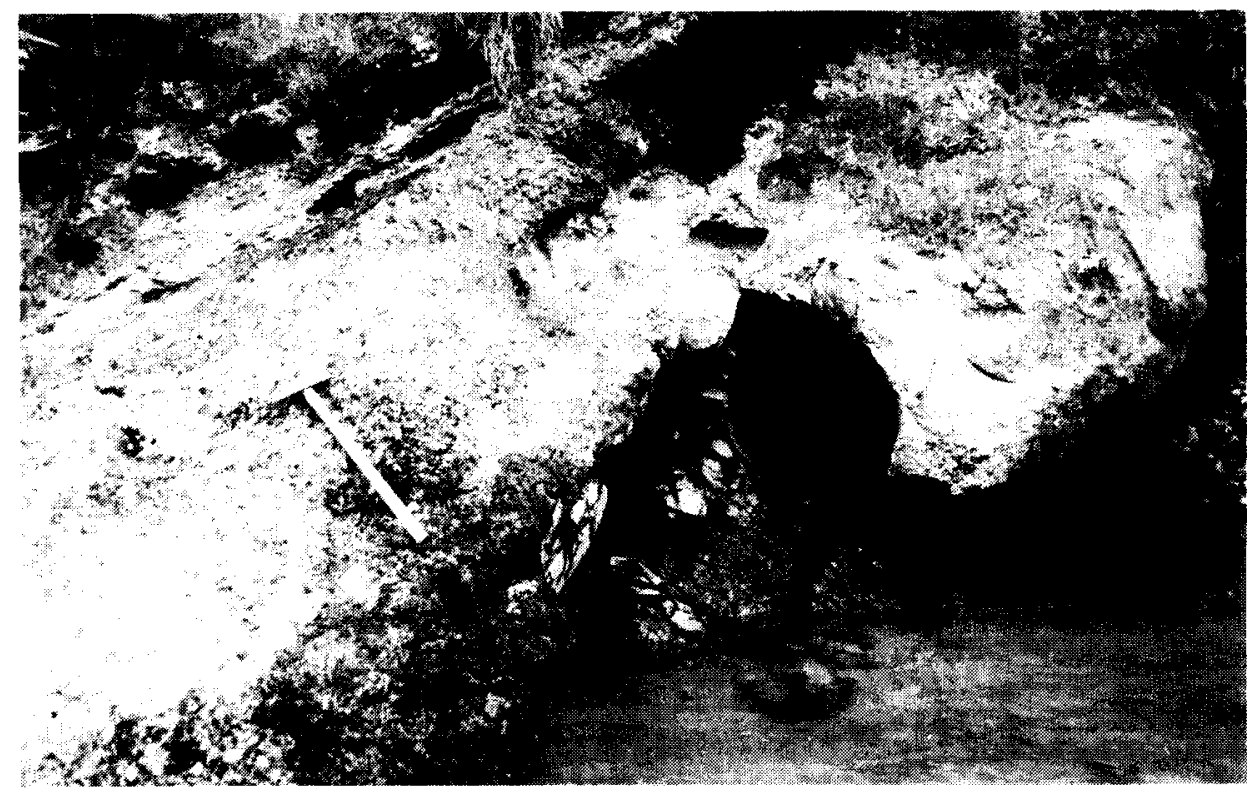

Fig. 11. Flamed contact between a conglomerate bed and underlying massive calcareous mudstone. Note incorporation of material from concretionary limestone layers in the mudstone into the base of the conglomerate, and the presence of mudstone shear partings within the conglomerate (upper left) (base of conglomerate packet $80 \mathrm{~m}$ above base of Waiau River Section, Fig. 5).

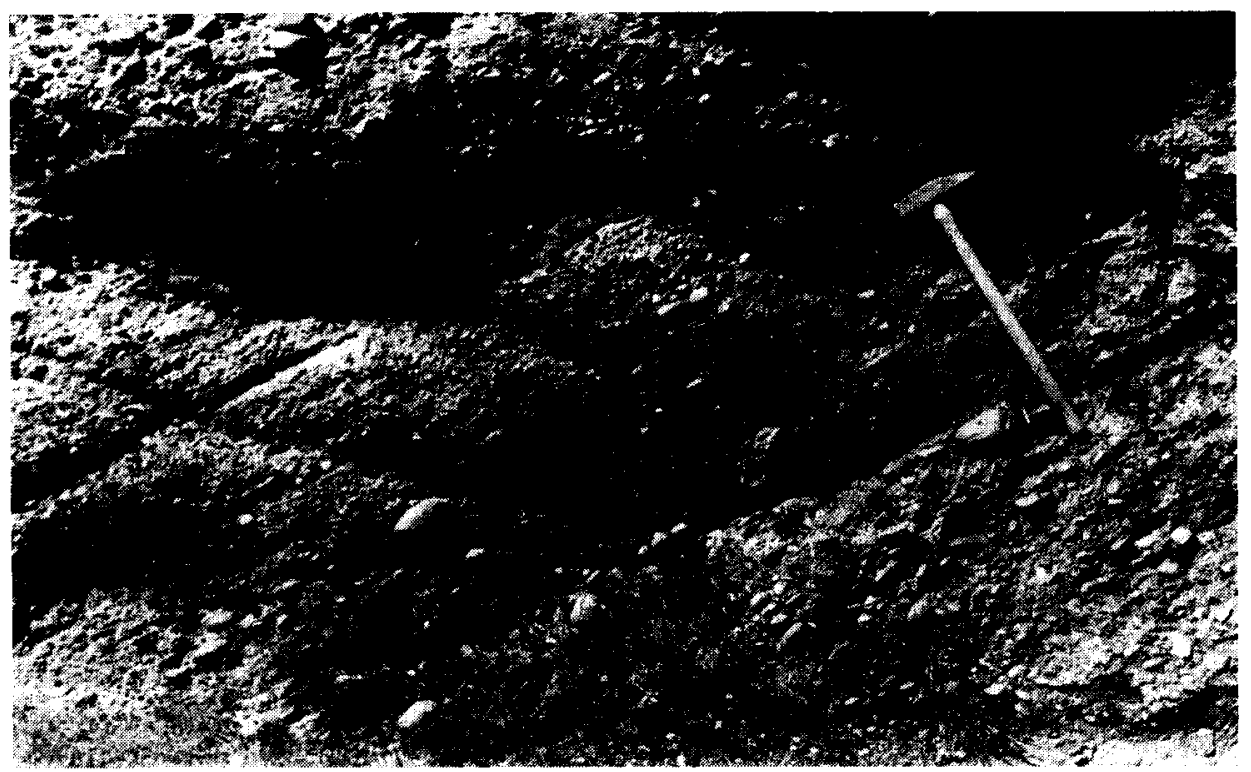

Fig. 12. Internal shear planes within a conglomerate, accentuated by subparallelism of long axes of clasts and spaced mudstone partings. Hammer $=80 \mathrm{~cm}$ long. Outcrop at foot of power pylon, north end of Conglomerate Ridge. 


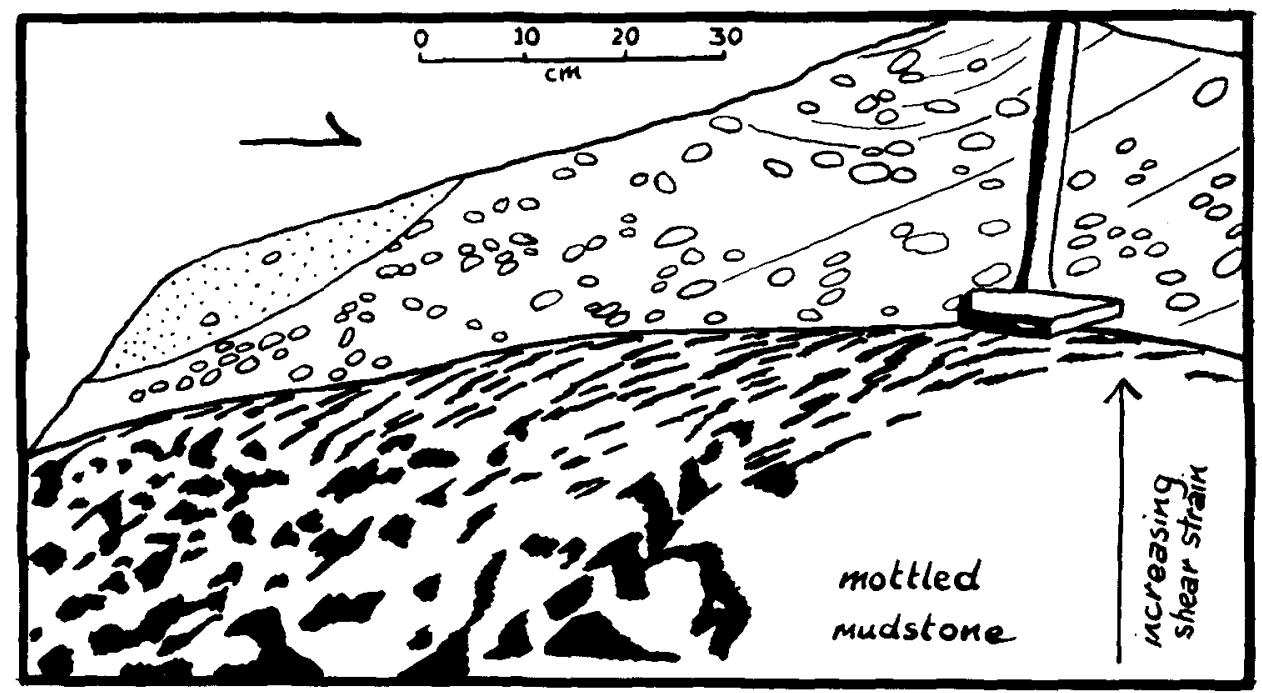

Fig. 13. Slide sheet of conglomerate overlying mudstone unit. Colour mottling in mudstone indicates increasing shear strain towards base of slide sheet. (Waiau River Section.) (Drawn from a photograph.) Black: calcareous mudstone.

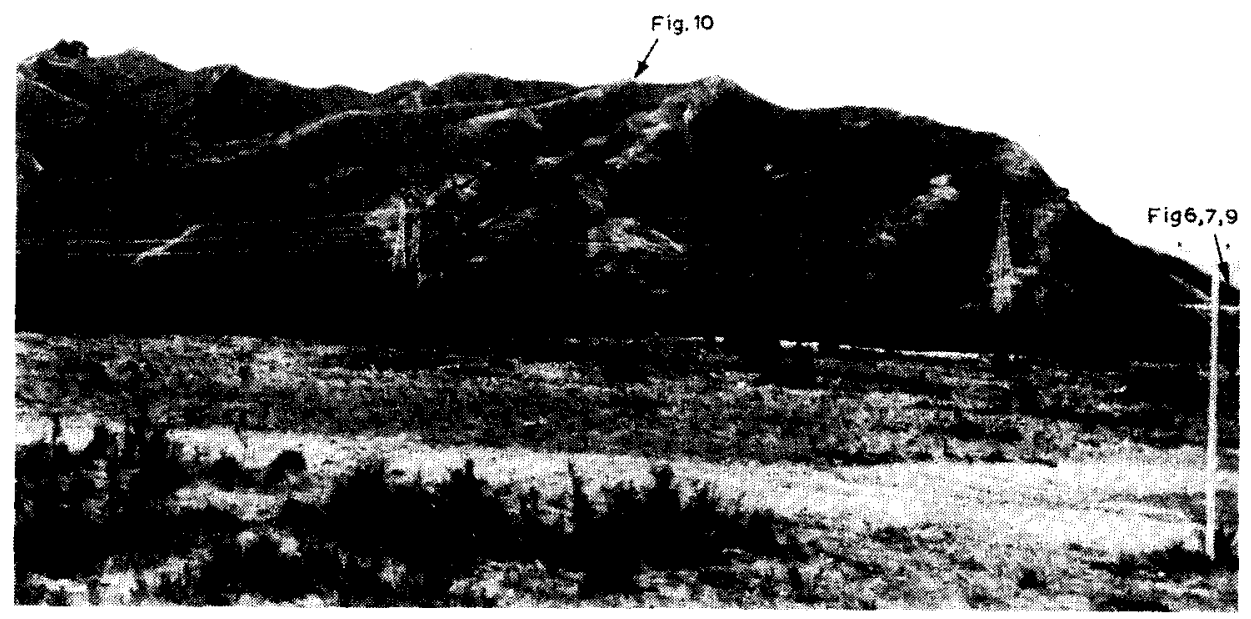

Fig. 14. View of Conglomerate Ridge from near Monowai township. Base of Monowai conglomerate at extreme right edge of photo (measured section of Fig. 6). Note inconsistency of dip of individual slide sheet in gully to right centre of photograph. Positions of other relevant figures indicated. 


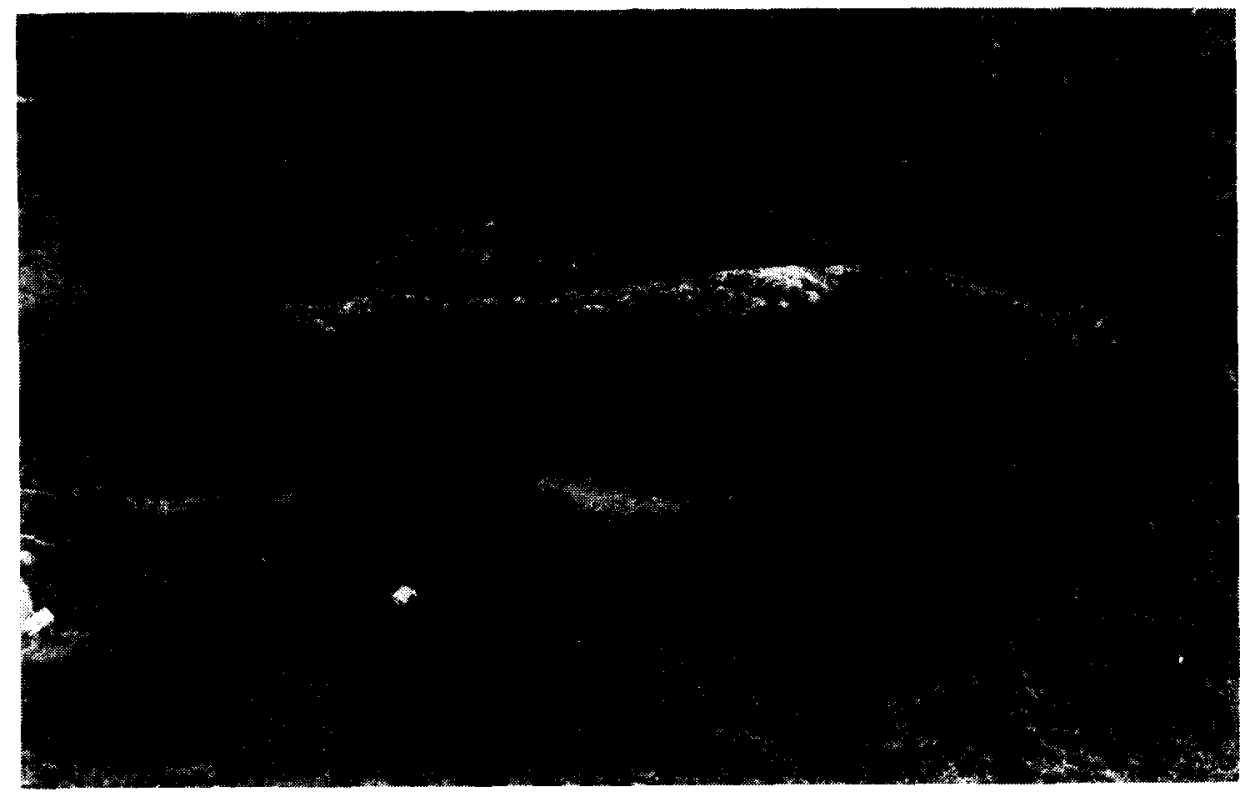

Fig. 15. Rotated slide sheet of conglomerate resting with sharp slide surface against upper parts of underlying conglomerate cycle (see Fig. 16 for detail). Hammer $=80 \mathrm{~cm}$ long.

They are demarcated below by a sharp planar shear surface, often coincident with a thin zone of sheared, lithified mudstone; less commonly shear surfaces are developed within an individual sheet. In a few examples, where the mudstone below is fairly thick, a progressive shear strain is developed in the top of the mudstone as the base of the overlying slide sheet is approached (Fig. 13). Many of the slide sheets were rotated during final emplacement, resulting in the internal fabric making angles of up to $30^{\circ}$ with the true bedding. The generally small size of individual slide sheets makes it impossible to trace individual bedding features far along strike. What look like strike ridges underlain by more or less homogeneous conglomerate units (cf. Fig. 14) are in fact horizons made up of numerous individual conglomerate slide-sheets. Redeposited conglomerates with sharp bases similar to those interpreted here as shear surfaces (Figs. 15-17) have been figured by several authors (e.g. Scott, 1966, fig. 22; Tyler, 1972, fig. 9).

Rock types within the slide sheets are similar to those already described from lower in the formation, though the finer-grained phases are dominated by medium to coarse lithic sand rather than mud and the intraslide-sheet organisation is generally irregular. Bedding within slide sheets is partly accentuated by layers of differing sand-conglomerate grain sizes, but particularly by a strong parallelism of clast long axes (cf. Fig. 12); similar fabrics have been described or figured by many authors (e.g. Tyler, 1972, fig. 9; Hendry, 1972). Though this pebble orientation is sometimes subparallel to the slide 


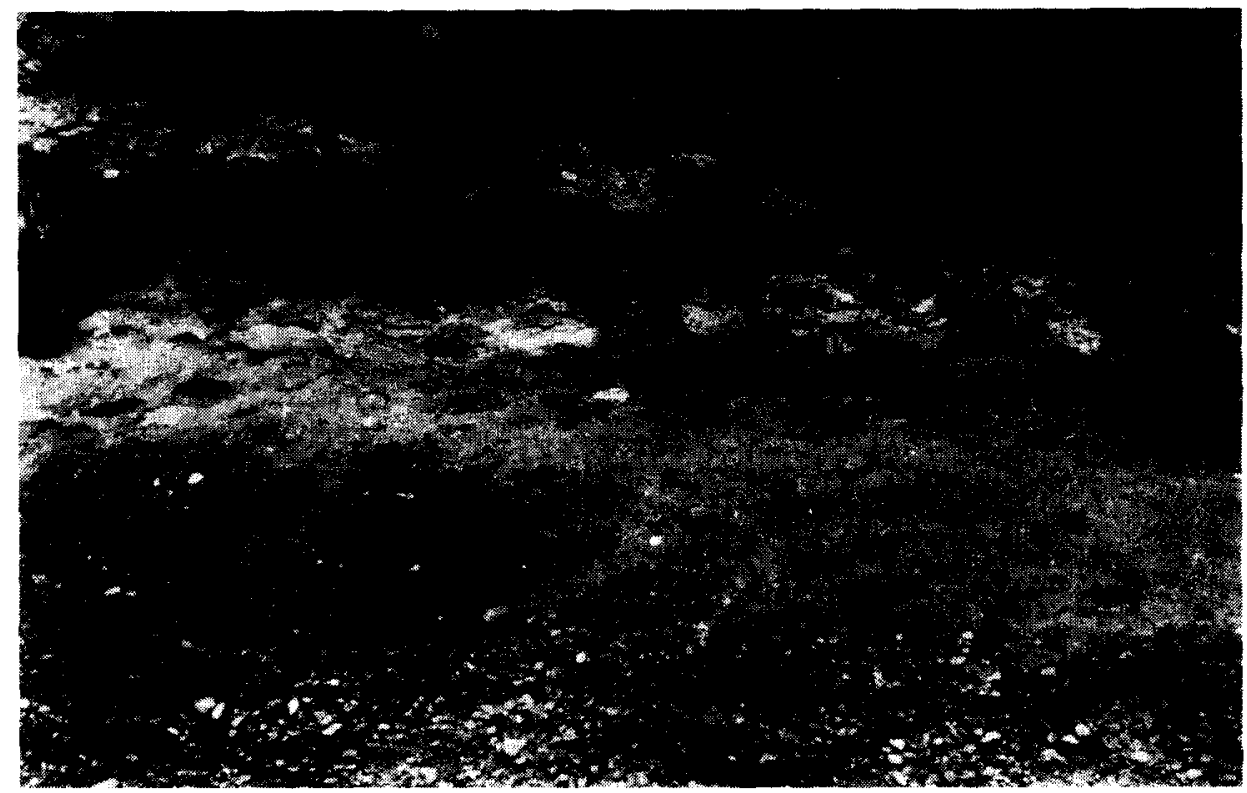

Fig. 16. Detail of Fig. 15, showing upper parts of lower conglomerate unit. Pebble conglomerate grades up through granular to coarse sand, to an horizon of penecontemporaneously derived mudstone balls (cf. Fig. 19).

surface at the base of the sheet, it is more usually rotated and butts into the basal slide surface at angles of up to $30^{\circ}$ (cf. Gennesseaux, 1966, fig. 19). In these cases, as for the slide sheets in sand-grade sediments described by Laird (1968), the very closest examination is required in order to show that the oblique surfaces are not traction cross-bedding (cf. Figs. 15, 17-18). Many previous investigators of redeposited conglomerates have stressed the general lack of features indicative of traction-current activity, yet have nonetheless recorded "cross-bedding" in coarse conglomerate phases. Our experience at Blackmount leads us to expect that much of this "cross-bedding" is rather a result of slide-sheet rotation of an original fabric developed parallel to the true bedding (e.g. Piper, 1970; Hendry, 1972, fig. 11; Stanley and Unrug, 1972, fig. 33; and cf. our Figs. 15-18 and Gennesseaux, 1966, fig. 19). We have insufficient data to generalise as to the sense of rotation of individual slide packets during final emplacement, and examples of both backward and forward rotation apparently occur.

Varying and usually irregular organisation of sand-conglomerate layers and lenses is seen within individual slide packets (Fig. 17). In some cases, however, there is a tendency for a regularly organized sequence of internal structures, somewhat analogous to the $X-Y-Z$ sequences described from lower in the sequence (Fig. 19a). In the typical case $70-90 \%$ of the thickness of the sheet is occupied by a homogeneous, poorly sorted conglomerate 


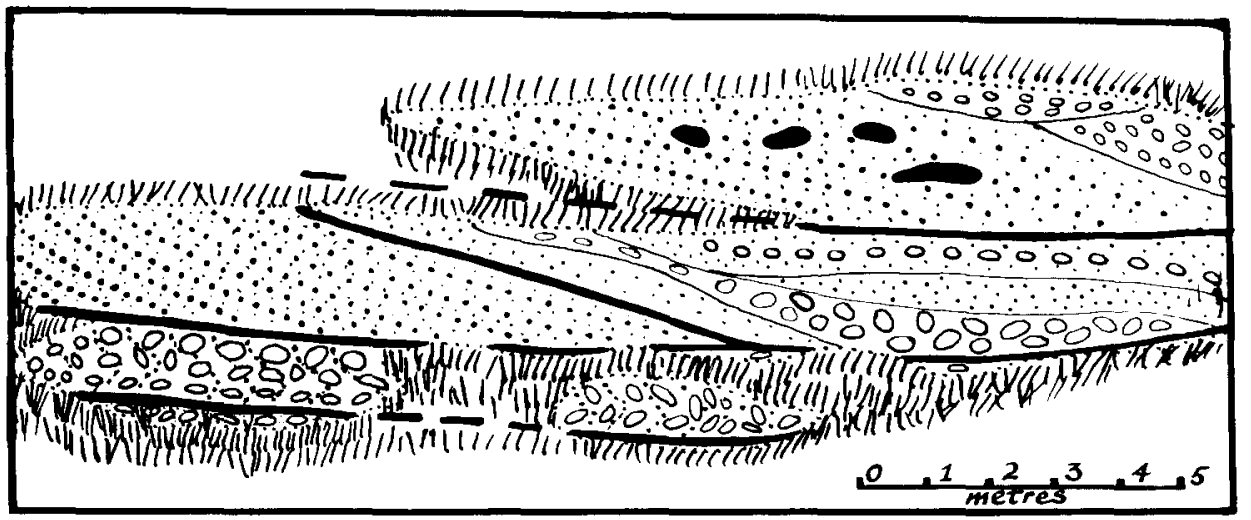

Fig. 17. Field sketch of several superposed slide sheets in a typical outcrop in the middle of the Conglomerate Ridge section.

or sandy conglomerate $(2-10 \mathrm{~cm}$ pebble diameter), containing mudstone clasts and bounded below by a sharp shear surface. The conglomerate grades swiftly up through pebble conglomerate (pebble size $1-3 \mathrm{~cm}$ ) to a granular sand with scattered pebbles. The top part of the bed (Fig. 16) invariably

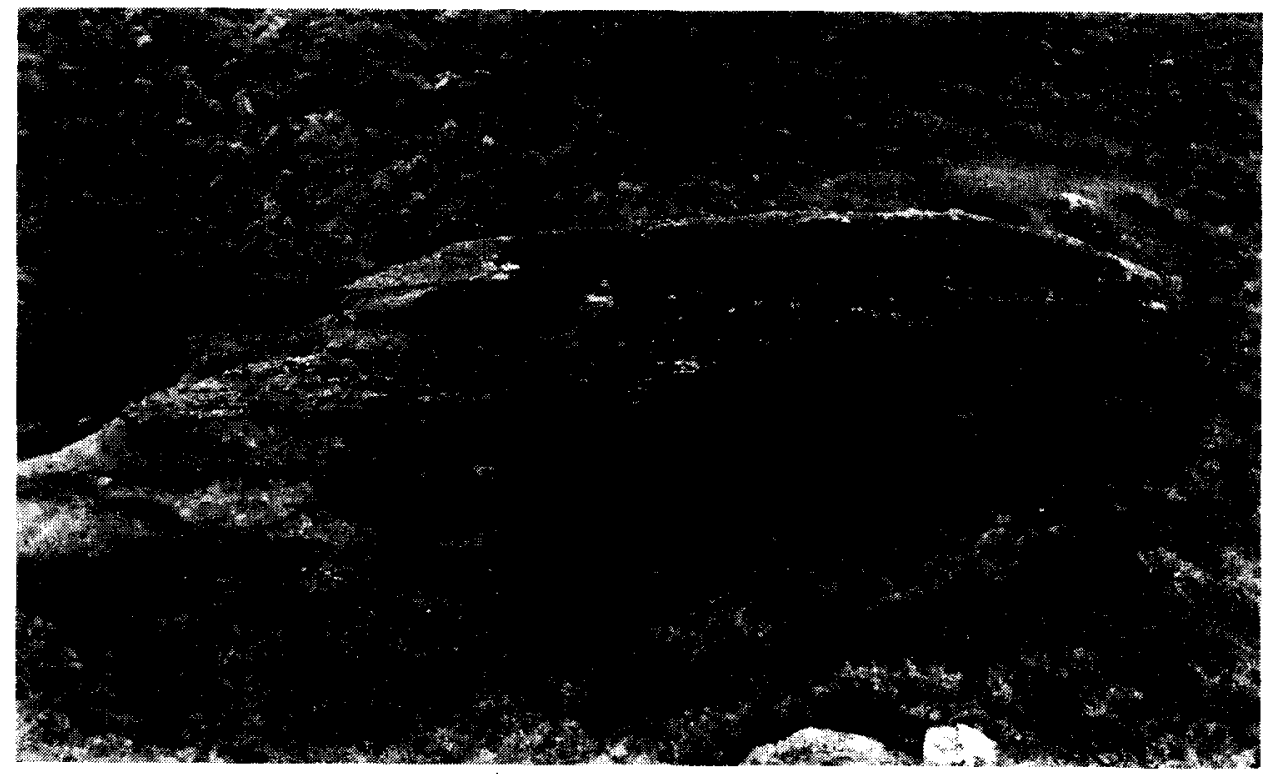

Fig. 18. Upper parts of a probable slide sheet within which is preserved pre-sliding sedimentation features. Note lateral continuity of graded conglomerate-sand beds, but that some beds (e.g. just above hammer head) are locally internally mixed and disrupted. Uppermost conglomerate unit is probably a rotated packet of parallel bedded congiomerate. Hammer $=80 \mathrm{~cm}$ long. 

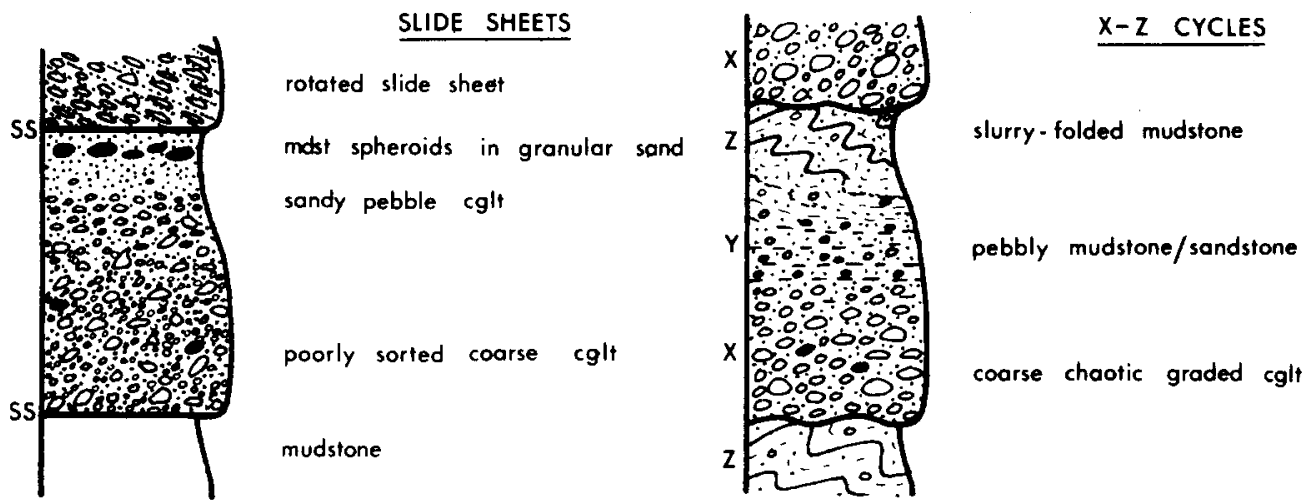

Fig. 19. Idealised sequences seen within (left) more mature slide sheets, and (right) typical $X-Y-Z$ sequence.

consists of a zone of subangular to well rounded mudstone clasts, some deformed, in a matrix of sand, sometimes pebbly. Somewhat similar poorly graded conglomerate-sand units have been described from the Jurassic breccias of the Nappe de la Brèche in the European Alps (Kuenen and Carozzi, 1953; Hendry, 1972), and from Kulm greywackes in Germany (Kuenen and Sanders, 1956). Occasionally (e.g. at the base of unit 3 of the Monowai River section; cf. Fig. 3), large rafts of sediment which retain traction structures may be preserved in the upper levels of such a slide conglomerate (figure in Carter and Norris, in prep.; and compare with Scott, 1966, fig. 23).

Some slide sheets retain bedding features that are probably related to the phase of sediment deposition immediately preceding the mobilization of the slide sheet. Such bedding features are generally preserved towards the top of a slide sheet (Fig. 18), and therefore they might be viewed as present within a raft similar to that just described from the Monowai River Section. However, these occurrences are in fact significantly different in that the upper parts of the sheet grade down into the underlying more homogeneous (but redeposited) conglomerate. The features residual from the previous sedimentary cycle comprise 50-100 cm thick units of graded conglomerate-sand, conspicuously uniform in thickness across $20 \mathrm{~m}$ of outcrop (Fig. 18). Bases are sharp, defined by concentrations of pebbles up to $5 \mathrm{~cm}$ in diameter. The conglomerate layer generally grades up to massive, faintly parallel laminated (rarely low-angle cross laminated) medium lithic sand with rare floating pebbles and mudstone clasts. In one instance only, the junction between the sand and conglomerate parts of such a bed apparently has burrows (?Ophiomorpha) penetrating down from the top of the conglomerate, suggesting a distinct (and ? traction) emplacement for each of the conglomerate and sand layers. In the same sheet, a steep-walled, conglomerate-filled channel, $2 \mathrm{~m}$ deep and $5 \mathrm{~m}$ wide, is cut into the graded conglomerate - sand layers. 
The grading, lack of conspicuous pebble imbrication and constancy of bed thickness of many of these graded beds make it unlikely that they were traction emplaced, and we infer deposition from proximal turbidity or fluxoturbidity currents. Thus in their present occurrence at least some of these graded conglomerate-sand beds are re-redeposited sediments, and a signal warning of the complexity of processes involved in proximal mass-transported facies.

Interpretation. A considerable literature exists on the description and interpretation of synsedimentary slide sheets, though most earlier writers have described features very much larger than those of the Monowai Formation, and have been primarily concerned with the "tectonic" rather than the sedimentary implications (Baldry, 1938; Barrington Brown, 1938; Beets, 1946; Kugler, 1953). Features of similar size to the Monowai Formation slides but in mostly sand-grade sediments have been described by Jones (1939) and Laird (1968). The experimental work of Rettger (1935) and the Recent slides described by Becker (1916) also involved fine-grained sediment, and the only detailed descriptions of small-scale slides in coarse sediments are apparently those of the breccias of the Nappe de la Brèche (Lemoine, 1967), and the most important descriptions and figures of Recent small-scale slide conglomerates in submarine canyons off Nice (Gennesseaux, 1966).

Most recent authors have followed the thesis of Dott (1963) and Morgenstern (1967) that submarine slides and slumps represent one end of a whole spectrum of subaqueous mass-transport processes. However, some writers have laid stress on the "mudflow" aspect of subaqueous mass movements (e.g. Dorreen, 1951; Shepard, 1951), and in the event of sediment mobilisation by spontaneous liquefaction or thix otropic change there is probably no preliminary stage at which the moving mass behaves as a "rigid" block bounded below by a single shear surface. Thus we may envisage at least two different ways in which most proximal mass-transported sediments are mobilised: (1) where initial failure is confined to a single shear plane, or to a narrow shear zone, on top of which travels a "rigid" raft of sediment; and (2) where initial failure is by liquefaction or thixotropy, when the sediment passes directly into a highly mobile inertia flow. Further transport of the sediment raft produced by an initial single shear failure ((1) above) will result in the homogenisation of its original internal stratigraphy by two main processes: (1) the development of multiple small-scale gravity faults at a high angle to original bedding (cf. Becker, 1916); and (2) the development of distributive internal shear subparallel to original bedding. By either or both of these mechanisms the originally "rigid" slide sheet is transformed into an inertia flow similar to one that may be produced directly by liquefaction or thixotropy ((2) above). With further transport, such an inertia flow may evolve its own characteristic assemblage of internal structures and fabrics and eventually (ex-hypothesi many authors) pass into a fluxoturbidity or turbidity current. 
The Monowai conglomerates provide support for the validity of such a model of slide-sheet evolution. The regional and stratigraphic setting of the slide sheets, together with their characteristic assemblage of features, points to deposition on a subaqueous marine slope, probably the frontal slope of a gravel delta. The processes by which initial mass-failure takes place in such environments have been well discussed by a number of authors (e.g. Morgenstern, 1967; Klein et al., 1972). Though the submarine slope involved at Blackmount may have been moderately steep, such steepness is not a prerequisite for the development of slide-sheets (Kuenen and Migliorini, 1950 and Lewis, 1971 have shown that sliding may develop in unconsolidated beds on slopes as little as $1^{\circ}$ ), though it may be a necessary precondition for the evolution of such slide sheets to more mature forms of mass transport.

Spontaneous liquefaction phenomena are most widespread in silt-grade sediments (Terzhagi, 1955), and most unlikely to occur in gravel or conglomerate. Therefore, the most likely cause of initial slide-sheet movement at Blackmount is the loading, and consequent failure by liquefaction, of the siltstone or mudstone that ubiquitously occurs beneath the Monowai slide sheets (cf. Crowell, 1957). As well-sorted pebbly sediments have little or no cohesion, it is likely that such a slide sheet would have been transformed rapidly into an inertia flow by the processes discussed above. Strata of sand/ mud grade within the conglomerate sequence generally possessed a higher cohesion, and are therefore often present within the remobilised conglomerates as rafts within which original sedimentary (traction) structures are preserved.

Within the Monowai slide sheets that preserve pre-sliding sedimentation structures (cf. Fig. 18), these are locally disrupted into patchy aggregates of mixed gravel-sand. Such local disruption probably marks the start of the homogenization of the entire bed by the development of laminar shear within the moving slide sheet (Fig. 12). Further transport led to full lithologic homogenization, followed by the development of secondary grain-size segregations, particularly normal grading (Fig. 19a). By this stage the mass was moving fast enough to erode the sea floor, the mudstone clasts so incorporated floated to the top of the flow (cf. Fig. 16), and pebbles throughout the bed often became oriented parallel to pervasive shear planes. When flows at this stage of evolution deposited, final deposition involved sliding along the sea floor with concomitant rotation of the whole packet, giving rise to an acute angle between the pebble orientation and the basal slide surface (cf. Figs. 15, 17; Gennesseaux, 1966; Williams et al., 1965). If, on the other hand, transport continued beyond this stage, and if sufficient mud was present in the flow, then successively more mature (differentiated) beds resulted until finally the typical $X-Y-Z$ graded sequence was produced (Fig. 19b). For the more mature flows, conditions were such that final deposition of the sediment took place without the development of basal slide surfaces (cf. Figs. 9-11).

Since the more mature mass-transported conglomerates are inferred to have travelled some distance from source, it is perhaps surprising that there is 
not more of a tendency for the development of typical turbidite structures in the Monowai conglomerates. Two explanations are worth discussing: (1) that sediments in the gravel-size ranges are too coarse grained to ever attain fully turbulent suspension (but note that Davies and Walker (1974) interpret conglomerates of this type as largely deposited from turbidity currents); or (2) that there has been an overemphasis on the gradation to be expected between proximal (slumping-sliding-inertia flow) and distal (fluxoturbidity-turbidity currents) mass-transport processes (cf. Dott, 1963; Morgenstern, 1967); the concept of a sudden hydraulic jump into the turbidity current phase may be more accurate (Van Andel and Komar, 1969), and it may be that none of the Monowai flows passed this critical barrier.

The general lack of evidence for turbidity currents is also significant in so far as it bears on the origin of the pebbly mudstones at Blackmount. Crowell (1957) argued for mobilisation of pebbly mudstones when "unstable gravel layers are laid down by turbidity currents on water-soaked mud". Our evidence rather supports the viewpoint of Stanley and Unrug (1972) and Gennesseaux (1966), that the original juxtaposition of gravel and mud is due to ordinary nearshore traction processes and that turbidity currents per se are not involved in the origin of most pebbly mudstones.

\section{CONCLUSIONS}

(1) The Monowai Formation conglomerates contain a variety of sedimentary features that together indicate deposition in delta-top and delta-slope environments. Regional stratigraphic and provenance data indicate that the Monowai conglomerate delta prograded from the north into a major marine flysch basin.

(2) The conglomerates that were deposited on the delta-slope were emplaced by a variety of subaqueous mass-transport mechanisms. A complete gradation exists between synsedimentary slide sheets within which pre-sliding sedimentation structures are preserved, and more mature mass flows which have developed their own internal sequence of structures during transport and deposition.

(3) By contrast with other described occurrences of redeposited conglomerates, there is a relative absence of reverse grading and pebble imbrication (as opposed to orientation parallel to pervasive shear planes or hydroplastic fold outlines) within the Monowai conglomerates.

(4) The more mature members of the mass-flow spectrum are variable, but have in common a more or less well-developed normal grading. This is the only feature seen which suggests that any of the Monowai conglomerates approached the turbidity-current end of the spectrum of subaqueous masstransport processes. It is not established that such grading unequivocally requires emplacement by turbidity currents. All other features of even the most mature conglomerates are rather consistent with emplacement from varying types of slide sheet or inertia flow. 
(5) An internal sequence of bedforms, the $X-Y-Z$ sequence, is characteristic of some of the more mature mass-emplaced units (Fig. 19b). These sequences are $2-10 \mathrm{~m}$ thick and are characterised by a lower $X$-division of bouldery conglomerate, a middle $Y$-division of pebbly mudstone or pebbly sandstone, and an upper $Z$-division of slurry-folded mudstone or sandstone. The $X-Y-Z$ sequences represent one of the more distal or mature types of redeposited conglomerates seen at Blackmount. Other less mature conglom. erate facies seen represent transport and deposition processes intermediate between slide sheets and the full $X-Y-Z$ sequence.

\section{ACKNOWLEDGEMENTS}

Financial support for this work was provided by the New Zealand Universities Grants Committee (both authors) and the Nuffield Foundation (RMC), to whom grateful acknowledgement is made. We also thank the landowners of the Blackmount area for permission to work on their properties, and particularly Mr. H.E. Robertson for his hospitality and help. We are grateful to Drs. E.G. Nisbett, H.G. Reading and N.A. Rupke for their critical reviews of the typescript, to Dr. G.H. Scott for his micropalaeontological determinations and to Professor de Jong for drawing our attention to the close similarities between the Monowai conglomerates and those described by Kruit et al. from northern Spain. Finally, one of us (RMC) particularly thanks Professors E.A. Vincent and D.R. Hunter and the staff of both the Oxford and Pietermaritzburg University Geology Departments for their hospitality during the period of leave in 1974-1975 when this paper was written.

\section{REFERENCES}

Aalto, K.R., 1972. Flysch pebble conglomerate of the Cap-des-Rosiers Formation (Ordovician), Gaspé Peninsula, Quebec. J. Sediment. Petrol., 42: 922-926.

Aalto, K.R. and Dott, R.H., 1970. Late Mesozoic conglomeratic flysch in southwestern Oregon, and the problem of transport of coarse gravel in deep water. In: J. Lajoie (Editor), Flysch Sedimentology in North America. Geological Association of Canada, Toronto, Ont., pp. 53-65.

Baldry, R.A., 1938. Slip-planes and breccia zones in the Tertiary rocks of Peru. Q. J. Geol. Soc. London, 94:347-358.

Barrington Brown, C., 1938. On a theory of gravitational sliding applied to the Tertiary of Ancon, Ecuador. Q. J. Geol. Soc. London, 94: 359-370.

Beck, A.C., 1964. Sheet 14 - Marlborough Sounds: Geological Map of New Zealand, $1: 250,000$. New Zealand Department of Scientific and Industrial Research, Wellington.

Becker, G.N., 1916. Mechanics of the Panama Canal slides. U.S. Geol. Surv. Prof. Pap., 98-N: 253-261.

Beets, C., 1946. Miocene submarine disturbances of strata in northern Italy. J. Geol., 54 : $229-245$.

Carter, R.M., 1975. A summary discussion of subaqueous mass transport with particular respect to grain-flows and fluxoturbidites. Earth Sci. Rev., 11: 145-177. 
Carter, R.M. and Norris, R.J., 1976. Cainozoic history of Southern New Zealand: an accord between geological observations and plate tectonic predictions. Earth Planet. Sci. Lett., 31: 85-94.

Carter, R.M. and Norris, R.J., in prep. The geology of the Blackmount area, western Southland.

Carter, R.M., Landis, C.A., Norris, R.J. and Bishop, D.G., 1974. Suggestions towards a high-level nomenclature for New Zealand rocks. J. R. Soc. N.Z., 4: 5-18.

Crowell, J.C., 1957. Origin of pebbly mudstones. Bull. Geol. Soc. Am., 68: 993-1010.

Davies, I.C. and Walker, R.G., 1974. Transport and deposition of resedimented conglomerates: the Cap Enrage Formation, Cambro-Ordovician, Gaspé, Quebec. J. Sediment. Petrol., 44: 1200-1216.

Dorreen, J.M., 1951. Rubble bedding and graded bedding in Talara formation of northwestern Peru. Bull. Am. Assoc. Pet. Geol., 35: 1829-1849.

Dott, R.H., 1963. Dynamics of subaqueous gravity depositional mechanisms. Bull. Am. Assoc. Pet. Geol., 47: 104-128.

Fisher, R.V., 1971. Features of coarse-grained, high-concentration fluids and their deposits. J. Sediment. Petrol., 41: 916-927.

Fisher, R.V. and Mattinson, J.M., 1968. Wheeler Gorge turbidite-conglomerate series, California; inverse grading. J. Sediment. Petrol., 38: 1013-1023.

Gennesseaux, M., 1966. Prospection photographique des canyons sousmarins du Var et du Paillon (Alpes Maritimes) au moyen de la Troika. Rev. Géogr. Phys. Géol. Dyn., 8: $3-38$.

Hendry, H.E., 1972. Breccias deposited by mass flows in the breccia nappe of the French Pre-Alps. Sedimentology, 18:277-292.

Hendry, H.E., 1973. Sedimentation of deep water conglomerates in lower Ordovician rocks of Quebec - composite bedding produced by progressive liquefaction of sediment. J. Sediment. Petrol., 43: 125-136.

Hoffman, P., 1973. Evolution of an early Proterozoic continental margin: the Coronation geosyncline and associated aulacogens of the northwestern Canadian shield. Philos. Trans. R. Soc. London, Ser. A, 273: 547-581.

Hubert, C., Lajoie, J. and Leonard, M.A., 1970. Deep sea sediments in the lower Paleozoic Quebec Supergroup. In: J. Lajoie (Editor), Flysch Sedimentology in North America. Geological Association of Canada, Toronto, Ont., pp. 103-125.

Johnson, A.M., 1970. Physical Processes in Geology. Freeman, San Francisco, Calif.

Jones, O.T., 1939. The geology of the Colwyn Bay district: study of submarine slumping during the Salopian period. Q. J. Geol. Soc. London, 95: 335-382.

Klein, G. de V., de Melo U. and Favera, J.C.D., 1972. Subaqueous gravity processes on the front of Cretaceous deltas, Recôncavo Basin, Brazil. Geol. Soc. Am. Bull., 83: 1469-1492.

Kruit, C., Brouwer, J., Knox, G., Schollenberger, W. and van Vliet, A., 1975. Une excursion aux côres d'alluvions en eau profonde d'age Tertiaire près de San Sebastian (Guipúzcoa, Espagne). Guide pour l'excursion Z-23, IXe Congrès International de Sédimentologie, Nice (France) $13-15$ juillet $1975.12-75 \mathrm{pp}$.

Kuenen, P.H. and Carozzi, A., 1953. Turbidity currents and sliding in geosynclinal basins of the Alps. J. Geol., 61: 363-373.

Kuenen, P.H. and Migliorini, C.I., 1950. Turbidity currents as a cause of graded bedding. J. Geol., 58: $91-127$.

Kuenen, P.H. and Sanders, J.E., 1956. Sedimentation phenomena in kulm and flozleeres grey wackes, Sauerland and Oberharz, Germany. Am. J. Sci, 254: 649-665.

Kugler, H.G., 1953. Jurassic to Recent sedimentary environments in Trinidad. Bull. Assoc. Suisse Géol. Ing. Pét., 20: 27-60.

Laird, M.G., 1968. Rotational slumps and slump scars in Silurian rocks, western Ireland. Sedimentology, 10:111-120. 
Lemoine, M., 1967. Breches sédimentaires marine à la frontière entre les domaines briançonnais et piemontais dans les Alpes occidentales. Geol. Rundsch., 56: 320-335.

Lewis, K.B., 1971. Slumping on a continental slope inclined at $1^{\circ}-4^{\circ}$. Sedimentology, 16: $97-110$.

Morgenstern, N.R., 1967. Submarine slumping and the initiation of turbidity currents. In: A.F. Richards (Editor), Marine Geotechnique. University of Illinois Press, Urbana, Ill., pp. $189-220$

Norris, R.J., Carter, R.M. and Turnbull, I.M., in prep. Cainozoic sedimentary basins adjacent to a major continental transform boundary, southern New Zealand.

Piper, D.J.W., 1970. A Silurian deep sea fan deposit in western Ireland and its bearing on the origin of turbidity currents. J. Geol., 78:509-522.

Rettger, R.E., 1935. Experiments on soft rock deformation. Bull. Am. Assoc. Pet. Geol., 19: 271-292.

Rocheleau, M. and Lajoie, J., 1974. Sedimentary structures in resedimented conglomerate of the Cambrian flysch, L'Islet, Quebec Appalachians. J. Sediment. Petrol., 44: 826836.

Sanders, J.E., 1965. Primary sedimentary structures formed by turbidity currents and related resedimentation mechanisms. In: G.V. Middleton (Editor), Primary Sedimentary Structures and Their Hydrodynamic Interpretation, Soc. Econ. Paleontol. Min eral., Spec. Publ., 12:192-219.

Scott, K.M., 1966. Sedimentology and dispersal pattern of a Cretaceous flysch sequence, Patagonian Andes, southern Chile. Bull. Am. Assoc. Pet. Geol., 50: 72-107.

Shepard, F.P., 1951. Mass movements in submarine canyon heads. Trans. Am. Geophys. Union, 32: 405-418.

Stanley, D.J. and Unrug, R., 1972. Submarine channel deposits, fluxoturbidites and other indicators of slope and base of slope environments in modern and ancient marine basins. In: J.K. Rigby and W.K. Hamblin (Editors), Recognition of ancient sedimentary environments. Soc. Econ. Paleontol. Mineral., Spec. Publ., 16: 287-340.

Terzhagi, K., 1955. Influence of geological factors on the engineering properties of sediments. Econ. Geol., 50th Anniv. Vol., 557-618.

Tyler, J.H., 1972. Pigeon Point Formation: an upper Cretaceous shoreline succession, central California coast. J. Sediment. Petrol., 42: 537-557.

Van Andel, T.H. and Komar, P.D., 1969. Ponded sediments of the Mid-Atlantic Ridge between $22^{\circ}$ and $23^{\circ}$ North latitude. Geol. Soc. Am. Bull., 80:1163-1190.

Williams, E.G., Guber, A.L. and Johnson, A.M., 1965. Rotational slumping and the recognition of slumping. J. Geol., 73:534-547.

Wood, B.L., 1966. Sheet 24 - Invercargill: Geological Map of New Zealand, $1: 250,000$. New Zealand Department of Scientific and Industrial Research, Wellington. 